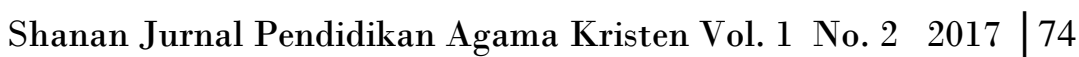

\title{
KAJIAN TEOLOGIS-PEDAGOGIS KETELADANAN RASUL PAULUS DALAM PENGINJILAN DAN RELEVANSINYA BAGI PENDIDIK KRISTEN MASA KINI
}

\author{
A Dan Kia \\ Universitas Kristen Indonesia \\ Program Studi Magister Pendidikan Agama Kristen \\ Danqh_dan@yahoo.co.id
}

\begin{abstract}
Abstrak
Peran guru Pendidikan Agama Kristen (PAK) dalam dunia pendidikan bukan saja hanya untuk mengajar bagi peserta didik, namun terlebih dari itu, guru PAK diharapkan dapat menjadi teladan bagi peserta didik. Untuk menjadi seperti yang dikehendaki Tuhan, maka seorang guru PAK harus memiliki figur yang dapat menginspirasi dirinya agar tetap semnagat dalam mengajar dan bertanggung selaku orang yang sudah diselamatkan. Dalam sejarah Perjanjian Baru para rasul begitu giat dalam mengabarkan Injil, tetapi yang paling terkenal dan sangat berpengaruh sepanjang sejarah hingga sekarang ialah rasul Paulus.

Rasul Paulus bukanlah satu-satunya orang Farisi yang menjadi Kristen (Kis. 15:15), tetapi ia yang paling terkenal. Untuk bisa mengerti panggilan, maka adalah baik untuk melihat kehidupannya. Perjalanan dan pelayanan Paulus memberikan suatu inspirasi bagi setiap pendidik kristen. hal dapat dilihat melalui pekerjaan dilingkungan pendidikan dalam konteks belajar mengajar. Proses belajar mengaajar bukan saja menjadi konten penting untuk mencapai tujuan pembelajaran, tetapi membaw misi Tuhan melalui kepribadian seorang pendidik agar menjadi surat Kristus/saksi yang hidup. Kesemunaya ini tercermin melalui pola hidupnya, komitmen, maupun misinya.

Dengan meneladani rasul Paulus, maka selayaknya pendidik kristen tetap setia dalam melaksanakan misiNya Tuhan dalam pelayanan, dan diharapkan untuk para pendidik pada akhirnya dapat mengemukakan pernyatan yang sama dengan yang dikemukakan rasul Paulus dalam salah satu suratnya "aku telah mengakhiri pertandingan dengan baik, aku telah mencapia garis akhir dan aku tela memelihara iman" (2 Tim. 4:7). Keteladan yang ditunjukkan oleh rasul Paulus dalam tangung jawabnya sebagai rasul, menunjukkan integritas diri sebagai seorang hambah Tuhan dalam melaksankan tangung jawab yang dipercayakan oleh Tuhan kepadanya. Contoh atau model yang ditujunkan oleh rasul Paulus tidak mudah untuk dilaksanakan, tetapi penyerahan total kepada Tuhan, memiliki komitmen yang jelas, menyadari diri sebagai hamba, nenghargai anugerah Tuhan, dan memiliki kasih,akan sangat memolong dalam melaksanakan tanggung jawab sebagai pekerja Tuhan yang berintegritas.
\end{abstract}

Kata kunci: Keteladanan, Rasul Paulus, Penginjilan, Pendidikan agama Kristen. 


\section{Pendahuluan}

Tugas seorang guru merupakan tugas yang mulia, karena di samping dapat melayani jemaat Tuhan, gurupun dapat menjadi seorang pengajar firman untuk bertumbuh dalam iman bagi setiap jemaat yang dilayaninya. Menurut Sidjabat, "Tugas mengajar merupakan pekerjaan yang mulia diperlihatkan oleh Paulus yang me-ngemukakan adanya karunia mengajar yang diberikan Allah kepada jemaat (Ef. 4:11-13; Rm 12:68)."1 Guru dalam hal ini seorang pendidik bertanggung jawab terhadap tindakannya dalam pengajarannya di lingkungan gereja dan masyarakat pada umumnya, sehingga guru jemaat perlu men-jadi seorang tokoh, panutan, dan identifikasi bagi jemaat di dalam lingkungan pe-layanannya. Oleh karena itu, guru perlu memiliki standar kualitas pribadi tertentu yang mencakup tanggung jawab, wibawa, mandiri, dan disiplin. Kualitas seorang guru merupakan sesuatu yang menentukan ke-berhasilannya dalam pelayanan.

Mutu pelayanan yang baik tergantung dari kualifikasi seorang guru yang profesional dan memiliki keahlian serta bertanggung jawab. Untuk itu hendaklah para guru memiliki kualifikasi yang memadai yang meliputi kompetensi intelektual, sosial, spiritual, pribadi moral dan profesional. Hal ini Ini berarti, seorang guru diharapkan memiliki kemampuan dengan pengetahuan, serta keterampilan untuk melayani jemaat yang adalah bagian dari tanggung jawabnya. Seorang guru sebaiknya adalah seorang yang sudah mengecap pendidikan teologi agar pemahaman tentang firman Tuhan dapat diajarkan sesuai aturan yang benar karena bagaian dari pelayanan firman adalah bagian dari pengajaran yang dapat membangun kepribadian tiap jemaat, karena iman bertumbuh dari pendengaran firman Kristus, (Roma 10:17). Demikian Boehlke mengutip pendapat Comenius ketika ia berbicara tentang pendidikan dan bahwa seorang

\footnotetext{
${ }^{1}$ B. S. Sidjabat, Menjadi Guru Profesional (Bandung: Kalam Hidup, 2000), 24.
}

gurupun diharapkan demikian karena kehidupan sendiri menjadi teladan pentingnya jabatannya dan perlunya dia diperlengkapi dengan pengetahuan dan keterampilan mengajar. ${ }^{1}$ Oleh karena itu, guru yang berkualitas penting dalam menjalankan tugasnya sebagai pelayan Tuhan. Namun, guru terkadang gagal di dalam menjalankan tugas, tanggung jawabnya dan tidak menunjukkan kualitas yang karena memgalami kejenuhan yang berkepanjangan dan tidak memiliki kerajinan untuk berkreatifitas serta mengikuti keinginan diri sendiri.

Watchman Nee mengatakan bahwa seorang pekerja Kristus adalah seorang yang memiliki kerajinan. ${ }^{2}$ Hal ini merupakan bagian terpenting untuk melayani agar dalam pelayananya yang ada menjadi maju karena adanya motivasi yang membangun diri sendiri dan dalam pekerjaan Tuhan. Jadi, ungkapan ini adalah ada guru yang memangku jabatan sebagai guru tetapi tidak berkualitas.

Dalam hal ini guru dituntut adanya tanggung jawab yang penuh dan berkualitas dalam menjalankan tugasnya sebagai pengajar, Sidjabat lebih lanjut menyatakan, kualitas guru PAK adalah guru yang menguasai materi pengajaran seperti pemahaman Kitab Suci, tetapi juga mencakup dimensi moral, etis dan spiritual, perkataan, tingkah laku, kasih, kesetiaan, dan kesucian hidup (1 Tim. 4:12,13,16). ${ }^{3}$

Surat 1 Timotius menjelaskan bagaimana rasul Paulus mengarahkan dan menasehati Timotius, sebagai seorang pengajar (guru) Injil dalam jemaat (1 Tim. 2:7; 2 Tim. 1:11). Timotius menyakini dia di panggil sebagai guru karena Injil Kristus. Dia merupakan pribadi yang berkualitas dalam pelayanan. ${ }^{4}$ Dia bertanggungjawab atas beberapa tugas yang di percayakan Gereja

\footnotetext{
${ }^{1}$ Robert R. Boehlke, Sejarah Perkembangan Pikiran dan Praktek Pendidikan Agama Kristen II (Jakarta: BPK Gunung Mulia, 2003), 61

${ }^{2}$ Watchman Nee, Pekerja Kristus (Bandung: Yayasan Kalam Hidup, 2003), 8.

${ }^{3}$ Sidjabat, Op.Cit, 24.

${ }^{4}$ Sostenes Nggebu, Pan patsaida Sampai Ke Yerusalem. (Malang: Kalam Hidup, 2002), 77.
} 
kepadanya terhadap sejumlah jemaah. ${ }^{5}$ Oleh karena itu, kepribadian Timotius perlu menjadi teladan bagi guru PAK.

Tujuan penulisan adalah untuk menjelaskan latar belakang pengajaran Paulus terhadap Timotius dan gambaran tentang guru PAK, dan Memaparkan pengajaran Paulus terhadap Timotius tentang kualifikasi guru PAK, serta menjelaskan aplikasinya bagi guru PAK.

Jika guru PAK memiliki kualifikasi sebagaimana pengajaran Paulus terhadap Timotius, maka guru PAK dapat melaksanakan tugas panggilan pelayanannya dengan penuh tanggung jawab.

\section{Latar Belakang Pengajaran Paulus Terhadap Timotius dan Gambaran Tentang Guru Pendidikan Agama Kristen}

\section{Latar Belakang Pengajaran Paulus Terhadap Timotius}

Dalam surat Timotius ini bersifat nasihat rasul Paulus kepada rekan sepelayanan yang masih muda yakni Timotius. Timotius memerlukan persiapan untuk melayani Tuhan sehingga surat ini dikirim kepada Timotius. Polhill mengatakan bahwa di tengah-tengah pengajaran yang telah mengacaukan persekutuan jemaat, mendatangkan kerusakan kepada setiap pribadi dan keluarga.

John B. Polhill menyatakan bahwa: Paulus bersama dengan umat yang konservatif berusaha dengan sungguhsungguh untuk melawan ancaman ini, dengan menekankan pengajaran yang sehat dan atas teladan pemimpin yang kuat. ${ }^{6}$ Oleh karena itu, Paulus menginginkan seorang pemimpin yaitu Timotius yang teguh dan kuat dalam mengurus rumah Allah. Tulluan mengatakan, Maksud pengajaran ini adalah untuk menolong Timotius dalam tugasnya rneng-

\footnotetext{
${ }^{5}$ Xavier Leon Dufour, Ensikiopedi Perjanjian Bam (Yogyakarta: Kanisius, 2008), 550

${ }^{6}$ John B. Polhill, Paul and His Letter (Nashville, Tennessee: Broadmao and Halman Publishers, 1999), 407.
}

gurukan jemaat di Efesus (1 Tim. 3:15), karena ada beberapa orang dalam jemaat itu yang mengajarkan ajaran lain dan sibuk dengan dongeng dan silsilah yang tiada putus-putusnya, yang hanya menghasilkan persoalan belaka, dan bukan tertib hidup keselamatan yang diberitakan Allah dalam iman (1 Tim. 1:4). Mereka hendak menjadi pengajar Hukum Taurat tanpa mengerti perkataan mereka sendiri (1 Tim. $1: 7){ }^{7}$ Oleh karena itu, kehadiran Timotius di tengahtengah jemaat dapat mengubah paradigma berpikir yang sia-sia ini. Timotius diharapkan dapat menjadi teladan bagi jemaat dan mampu mempertahankan Injil sebagai kebenaran dan Yesus Kristus sebagai dasar kebenaran itu. Sehingga surat ini penting bagi Timotius sebagai pedoman hidupnya dalam pelayanan.

Donald Guthrie dalam buku New Bible Commentary. Consulting mengatakan bahwa Surat 1 Timotius bertujuan untuk memberikan beberapa nasihat atau bimbingan atas persoalan dari kehendak pengurus Gereja dan menentang pengajar sesat Seperti tertulis dalam 1 Timotius 3:14-15, Paulus dengan jelas bermaksud mempersiapkan Timotius dengan kebutuhan bimbingan, dimana Paulus tidak bertemu Timotius lagi. ${ }^{8}$ Harapan dan masa depan Gereja saat itu terletak pada kepemimpinan Timotius dalam menggurukan jemaat Tuhan dengan benar. Dengan demikian Timotius bertanggungjawab penuh dalam melaksana-kan tugas ini.

Surat ini bertujuan untuk menolong Timotius baik secara pribadi maupun dalam pelayanannya. Harapan kepada Timotius sebagaimana dalam 1 Timotius 4:12 yang berbunyi, "Jangan seorang pun menganggap engkau muda, jadilah teladan bagi orangorang percaya, dalam perkataanmu, dalam tingkah lakumu, dalam kasihmu, dalam kesetiaanmu dan dalam kesucianmu". Inilah

\footnotetext{
${ }^{7}$ Ola Tulluan, Introduction Perjanjian Baru, (Jakarta: Yayasan Persekutuan Pekabaran Injil Indonesia (YPPII), 1999), 224.

${ }^{8}$ Donald Guthrie, New Bible Commentary. Consulting Editors D. A. Carson, (Leicester, England: InterVarsity Press, 1994), 1293.
} 
yang diharapkan Paulus sebagai hamba Allah kepada Timotius dalam surat ini.

\section{Latar Belakang Timotius}

Timotius dilahirkan di Listra dari seorang ayah berbangsa Yunani dan ibunya berbangsa Yahudi bernama Eunike dan neneknya bemama Lois (2 Tim, 1:5). Menurut Tenney, dia dididik dalam adat istiadat Yahudi dan diajari kitab suci sejak masih kanak-kanak. ${ }^{9}$ Ini berarti, Timotius telah mendapat pengajaran Kitab Suci sejak kecil dalam keluarga sebelum menjadi pelayan Tuhan.

Nama Timotius memiliki pengertian sebagai seorang yang menghormati Allah dalam hidupnya, Dari nama Timotius ada kesan bahwa dia adalah seorang yang takut kepada Allah. Timotius, seorang anak rohani dan rekan yang dikasihi Paulus. Dia adalah hasil pelayanan yang bertobat pada pelayanan misi kedua Paulus. Tenney mengatakan, "Paulus menjadikan Timotius menjadi muridnya dalam perjalanan yang kedua (Kisah, 16:1-3), dan sejak itu Timotius selalu menyertai Paulus kemana pun ia pergi. ${ }^{10}$ Pelayanan Paulus di Listra, seperti terdapat dalam Kisah Para Rasul 14:1-10, berpengaruh besar terhadap Timotius yang pada masa itu kira-kira berumur 15 tahun. Tujuh tahun kemudian ia mulai mengikut Paulus dalam penginjilan. ${ }^{11}$ Berdasarkan pernyataan di atas, penulis menyimpulkan bahwa Timotius mulai melayani kurang lebih 22 tahun. Usia ini bila dibandingkan dengan ketentuan dalam tradisi orang Yahudi masih terlalu muda untuk mengemban tugas kepemimpinan Gereja. Stott mengemukakan alasan sebagai berikut: Pertama, Tradisi. Dua ukuran yang diakui orang Yunani atau Romawi yakni neos dan geron, juvenis dan senex. Kata neos dan juvenis sekali-kali tidak mengadung konotasi kurang baik seperti "kekanak-kanakan". Kata itu dipakai untuk

\footnotetext{
${ }^{9}$ Merrill C. Tenney, Survei Perjanjian Baru, (Malang: Gandum Mas. 2006), 414.

${ }^{10}$ Tenney Op.Cit,

${ }^{11}$ Chapman, Op.Cit, 114.
}

orang dewasa yang sedang berada pada puncak kekuatannya dan untuk usia wajib militer sampai mendekati usta 40 tahun. Usia tiga puluan masih terlalu mudah untuk mengemban tugas kepemimpinan Gereja seperti yang diperhadapkan kepada Timotius. Kedua, Timotius merasa tidak mampu, karena kondisi fisik yang sering sakit seperti sakit kambuh mudah kalah muka, segan menghadapi orang dan suatu tugas yang sukar. Ketiga, orang lain yang meremehkan Timotius karena menganggap dia rendah (1 Kor. $16: 10-11)^{12}$

Umur muda bukan alasan untuk tidak melayani Tuhan. Hati yang mau berserah diri kepada-Nya itulah yang Tuhan kehendaki dan Tuhan pakai sebagai alat-Nya. Melayani Tuhan merupakan perkara besar, tidak semudah membalikkan telapak tangan, tetapi melalui suatu proses hidup. Tantangan dan masalah merupakan suatu yang perlut dilalui oleh seseorang. Timotius menghadapi ajaran sesat (Gnostik) yang merupakan tantangan dalam pelayanannya. Akan tetapi keteguhan hati pada panggilan Tuhan dapat melalui tantangan yang ada (1 Tim. 1: 18-20). Selama bersama-sama dengan Paulus, Timotius menunjukkan kesetiaan dan kesungguhan hati yang mendalam dalam melayani Tuhan (Flp. 2:19-21). Itu sebabnya surat yang memakai namanya ini dimaksudkan untuk membesarkan hati dan meneguhkan dia untuk menerima tugas berat yang dilimpahkan Paulus kepadanya. ${ }^{13}$ Timotius seorang muda yang sebenarnya belum layak melayani Tuhan, tetapi Tuhan membuatnya besar dan berhasil karena dia setia dan teguh dalam panggilannya sebagai pelayan Tuhan.

Gereja memburuhkan pemimpinpemimpin, karena faktor kepemimpinan itu menimpakan bagian yang mutlak dari seluruh hidup, pekerjaan dan organisasi Gereja. Karena, tugas pemimpin adalah untuk menjaga agar pengajaran-pengajaran di-sampaikan dengan benar dan ditanamkan dengan teguh dalam kehidupan umat Kristen. Di tengah-tengah umat Kristen yang dikacau-

\footnotetext{
${ }^{12}$ Stott, Op.Cit, 25.

${ }^{13}$ Tenney. Op.Cit,. 415.
} 
kan oleh pengajaran-pengajaran sesat, diperlukan pengatur yang baik. Oleh sebab itu, pentingnya pemimpin jemaat Allah dalam menggurukan gereja-Nya ke jalan yang benar. Allah menghendaki Gereja-Nya bertumbuh dewasa dalam iman serta men-dapat pengajaran yang berasal dari firman Tuhan. Sebab mereka menjadi milik Allah dan Allah menjadi milik mereka. Artinya Gereja lahir dari inisiatif Allah dalam memilih GerejaNya. ${ }^{14}$ Timotius mendapat panggilan untuk me-layani jemaat Allah di Efesus. Haak menyatakan bahwa sebelum Paulus berangkat ke Makedonia, Timotius diteguhkan menjadi penginjil di Efesus. ${ }^{15}$ Jelas bahwa sesuai panggilan Timotius melayani Tuhan, maka Tuhan mempercaya-kan pelayanan kepada dia untuk melayani jemaat Allah di Efesus (1 Tim. 1:3).

Dari penjelasan di atas jelas di jemaat Efesus ini telah berkembang ajaran sesat ${ }^{16}$ dan memerlukan pengaturan baik serta pengajaran yang benar. Melalui inilah Timotius memenuhi panggilannya sebagai penjaga ajaran sehat, melalui dialah Gereja mendapat pelayanan yang sehat. ${ }^{17}$ Ini berarti, panggilan Timotius bertujuan untuk mempertahankan ajaran sehat yaitu firman Allah serta mengabarkannya kepada orang lain.

Pelayanan ini merupakan panggilan Timotius untuk melayani Tuhan. Menurut Barclay, salah satu tugas panggilan Timotius adalah untuk memelihara 'kebenaran yang

\footnotetext{
${ }^{14}$ Millard J. Erickson, Teologi Kristen hlm. 3, (Malang: Gandum Mas, 2003), 291.

${ }^{15}$ Haak, Op.Cit, 4.

${ }^{16}$ Alasan timbulnya ajaran sesat di Jemaat Efesus karena orang-orang di Efesus salah menggunakan hukum Taurat Perjanjian Lama. Pengajar sesat itu tidak mengerti isi dan maksud dari hukum Allah. Sehingga sehingga menyebabkan orang-orang yang sudah percaya melepaskan kemerekaan yang mereka peroleh karena kasih kanmia Kristus (Gal. 5:1) dan membuat mereka hidup di dalam perhambaan dibawah ajaran-ajaran agama Yahudi. Sumber Wiersbe, Setia Di Dalam Kristus. Op.Cit, 17.

${ }^{17}$ David L. Bartlett. Pelayanan Dalam Perjanjian Bam, (Jakarta: BPK Gunung Mulia, 2003), 209.
}

dipercayakan kepadamu (2 Tim. 1:14). ${ }^{18}$ Dalam tugas panggilan ini bukanlah maksudnya supaya dia memerintah dengan kekerasan, melainkan supaya menggurukan dan mengantar Gereja Tuhan dengan memberi nasihat dan pengajaran yang sehat.

Kebenaran yang dimaksudkan adalah firman Tuhan. Oleh sebab itu, Paulus mendorong Timotius untuk melindungi jemaat, sama seperti seorang guru perlu melindungi dombanya melawan serigalaserigala yang ganas (Kis. 20:28-32). Ajaran sesat yang mengancam kehidupan Gereja (Gal. 1:6-10). Hal-hal ini Paulus menyebutkannya sebagai dongeng dan silsilah (1 Tim. 1:4). Dongeng berarti cerita-cerita hidup dalam masyarakat mengenai nenek moyang dan tokoh yang hidup pada masa lampau yang dianggap masyarakat sebagai pahlawan, Ini bukan sekedar dipakai untuk menggambarkan cerita yang dikarang-karang ataupun legenda tetapi cerita-cerita tersebut diubah sedemikian rupa sehingga menggantikan ajaran Kristen yang benar. Silsilah berarti daftar keturunan. ${ }^{19}$ Timotius diharapkan melepaskan domba Allah dari pengetahuan ini, dan membawa kepada pengguruan kebenaran Allah. Ini berarti, panggilan Timotius adalah memberitakan ajaran sehat dalam melawan ajaran sesat berdasarkan Injil dari Allah yang mulia (1 Tim. 1:11).

Dasar panggilan ini adalah 1 Timotius 3:15 yang menjelaskan supaya engkau (Timotius) tahu bagaimana perlu hidup sebagaimana keluarga Allah yakni jemaat dari Allah yang hidup, tiang penopang dan dasar kebenaran. Supaya engkau tahu bagaimana hidup sebagai keluarga Allah artinya hubungan dia dengan jemaat setempat sebagai pembawa kebenaran. Agar tiap jemaat menikmati kehadiran nyata dan Allah

\footnotetext{
${ }^{18} \mathrm{H}$ William Barclay, Surat 1 dan 2

Timotius.Titus. Filemon. (Jakarta: BPK Gunung Mulia, 2001), 13.

${ }^{19}$ Daniel C. Arichea dan Howard A. Hatton, Pedoman Penafsiran Alkitab Surat-Surat Pauius Kepada Titus, (Jakarta: Lembaga Alkitab Indonesia (LAI), 2004), 12.
} 
yang hidup. ${ }^{20}$ Timotius diharapkan membangun hubungan baik dengan sesama, memberikan teladan serta mengasihi orang lain sama seperti Allah mengasihi umat-nya (1 Yoh, 4:19). Gereja adalah penyokong dan landasan dari kebenaran. Artinya dalam lingkungan kesaksian dia kepada dunia. Kristus adalah kebenaran itu sendiri, merupakan satu-satunya landasan Gereja (1 Kor. 3:11). Kebenaran adalah 'Injil' atau'firman kebenaran'(Rm. 2:16; Gal. 2:15; dan Kol. 1:5). ${ }^{21}$ Ini berarti Yesus adalah fondasi Gereja satu-satunya karena Allah yang mendirikan jemaat-Nya (Mat. 16:18), dan kebenaran hanyalah terdapat di dalam Injil. Kehadiran Timotius memberitakan hal ini kepada orang lain supaya mereka mengenal siapa Yesus dan kebenaran-Nya serta merasakan dan menikmati hadirat Tuhan dalam hidup mereka. Jadi, panggilan Timotius berasal dari Allah, karena Allah yang memilih Timotius sebagai alat memberitakan firman kebenaran-Nya.

Tugas memberitakan firman adalah tugas yang Paulus lakukan sesudah ia dipanggil menjadi rasul di antara orang-orang kafir (Gal. 2:7; 2 Tim. 1:9-11). Tugas yang sama dia wajibkan kepada Timotius untuk meneruskannya. ${ }^{22}$ Tugas sebagai pemberita Injil adalah memproklamasikan Injil yakni Yesus Kristus yang telah mati dan bangkit (1 Kor. 15:3-4). Kata memberitakan merupakan kata perintah yang di tunjukkan kepada Timotius, "Beritakanlah firman, siap sedialah baik tidak baik waktunya, nyatakanlah apa yang salah, tegur dan nasehatilah dengan segala kesabaran dan pengajaran (2 Tim. 4:2). Perkataan bentakanlah (keruxon ton logon) merupakan kalimat imperatif yang ditunjukkan kepada Timotius. ${ }^{23}$ Kalimat itu mengandung makna bahwa apa yang Paulus katakan dalam ayat 2 merupakan suatu

${ }^{20}$ A. M. Stibbs, Tafsiran AlkitabMasa Kini.(Jakarta: Yayasan Kristen BinaKasih (YKBK), 2007). 694.

${ }^{21}$ Pfeiffer dan Harrison, Op.Cit, 872.

${ }^{22}$ P. D. Latuihamalo, dkk., Berakar Di Dalam Dia dan Di Bangun DJ Alas Dia. (Jakarta: BPK

Gunung Mulia, 2005), 16.

${ }^{23}$ Ibid, 43 anianat yang berkaitan dengan pemberitaan firman. Amanat ini Paulus sampaikan kepada Timotius untuk dilakukan. ${ }^{24}$

Maksud Paulus dengan firman adalah firman Allah atau firman kebenaran (2 Tim. $2: 9,15)$. Kata siap sedialah (epistethi) melakukan tugas itu baik atau tidak baik waktunya. Perintah ini mengandung makna bahwa seorang pelayan firman perlu siap sedia (tidak mengenal situasi dan keadaan apapun) untuk memberitakan firman Allah baik senang maupun susah. Termasuk dalam tugas pemberitaan firman adalah menyatakan kesalahan, untuk memperbaiki kelakuan dan untuk mendidik orang dalam kebenaran (2 Tim. 3:16). Pfeiffer dan Harrison mengatakan, "Pelaksanaan tugas ini bukan hanya memelihara iman melalui perbuatan baik dan perilaku yang benar di rumah Allah saja, tetapi juga penolakan iman yang salahpalsu. ${ }^{25}$ Dalam tugas ini Timotius berhadapan dengan guru-guru palsu yang menyebarkan ajaran sesat. Di antaranya Himeneus dan Filetus yang mengatakan kebangkitan manusia telah berlangsung (1 Tim. 1:20;2 Tim. 2:17) dan Aleksander yang disebut sebagai orang yang banyak melakukan kejahatan (1 Tim. 1:20;2 Tim, 4:14). Karena itu, Timotius perlu mengungkapkan kesalahan itu melalui firman Allah.

Dalam tantangan berat melayani jemaat Efesus, Paulus menguatkan Timotius melalui tugas panggilannya. 1 Timotius 1:1820 merupakan ayat peneguhan sebuah panggilan pelayanan sejati yang berasal dari Allah. Dalam hal ini, Timotius menerima tugas pelayanan ini bukan dari manusia atau kehendaknya sendiri, melainkan anugerah dari Allah. Ketika dia diutus dan dikhususkan untuk melayani Tuhan, Timotius telah menerima nubuat atau konfirmasi yang berdasarkan firman Tuhan dan peneguhan tugas panggilan melalui penumpangan tangan para penatua (1 Tim. 4:14). Artinya adalah Timotius melayani bukan semata-mata keinginannya sendiri, tetapi sebuah tugas

\footnotetext{
${ }^{24}$ Latuihamalo, Op.Cit, 56

${ }^{25}$ Pfeiffer dan Harrison, Op.Cit, 859.
} 
yang disahkan melalui dan pentahbisan. ${ }^{26}$ Ini berarti Timotius dengan sah mendapat tugas ini melalui para penatua sebagai wakil Allah.

Tugas ini merupakan tongkat estafet pelayanan Gereja. Sebagaimana Musa menugaskan Yosua, Elia menugaskan Elisa dan Tuhan Yesus menugaskan para rasulNya, demikianlah Paulus menugaskan Timotius. Demikian pula, sebagaimana Musa mengakhiri penugasanya dengan memberitakan nasihat bagi seluruh Israel dan Kristus bagi seluruh Gereja. Paulus mengakhiri penugasannya dengan sebuah berkat "Kasih karunia beserta kamu" 6:21. ${ }^{27}$ Ini berarti, Paulus mengalihkan tugas tersebut kepada Timotius seperti yang telah dilakukan oleh Musa, Elia, dan Tuhan Yesus. Jadi, tugas panggilan Timotius adalah memberitakan firman kebenaran Allah yang merupakan tanggung jawab besar yang diberikan kepadanya dan disahkan melalui pentahbisan oleh para penatua.

\section{Gambaran Tentang Guru PAK}

Guru merupakan unsur penting dalam kegiatan mengajar. Sidjabat mengutip pendapat Brian V. Hill dalam bukunya (Faith At the Blackboard Facing the Cristian Teacher, 1982) mengatakan bahwa, Gurulah yang membimbing peserta didiknya untuk belajar mengenal, memahami, dan menghadapi dunia tempat ia berada. Dunia di sini termasuk dunia ilmu pengetahuan, dunia iman, dunia karya, dan dunia sosial budaya. Guru merupakan jembatan dan sekaligus agen yang memungkinkan peserta didik berdialog dengan dunianya. Guru terpanggil untuk mendorong peserta didik menimba pengetahuan, pemahaman atau bahkan memberi kontribusi bagi dunianya." 28

Itu berarti, bahwa peranan guru dalam mengajar adalah mentrasfer pengetahuan kepada peserta didik, membawa peserta didik

\footnotetext{
${ }^{26}$ Ibid, Op.Cit, 875.

${ }^{27}$ Pfeiffer dan Harrison, The Wycliffc Bible

Commentary, 875.

${ }^{28}$ Sidjabat, Op.Cip, . 29.
}

mengenali dirinya di mana dunia berada. Guru mendidik peserta didik kepada moral, nilai-nilai hidup manusia dan membangun spiritual peserta didik. Dengan ini peserta didik dapat berinteraksi dengan dunia lingkungan dia berada dan juga takut akan Tuhan (Ams 1:7). Karena itu guru mempunyai peranan dan tanggung jawab dalam proses pendidikan peserta didik.

Guru PAK perlu berakar dalam pemahaman iman Kristen dan komitmen kristiani yang teguh serta mendasar. Karena iman Kristen bersumber dari kebenaran dan prinsip-prinsip firnan Tuhan sebagaimana dituliskan dalam Alkitab yang merupakan pedoman hidup setiap orang Kristen. Dengan kata lain, nilai-nilai iman kristiani mewarnai guru PAK dalam mengemban tugas dan panggilan keguruan, baik di keluarga, Gereja, masyarakat maupun di sekolah.

Jabatan guru PAK merupakan karunia khusus dari Allah melalui Roh Kudus kepada setiap guru PAK (1 Kor. 12:11, 28). Ini berarti guru PAK merupakan titian Allah untuk mengajar firman-Nya. Dengan demikian guru PAK adalah guru yang hidup di dalam firman Tuhan dan sikap yang rnencerminkan sebagai wakil Allah, karena guru PAK terpanggil untuk bertumbuh ke arah pengenalan yang mendalam tentang pribadi Kristus (Kol. 2:6-7).

Dalam Perjanjian Lama, khususnya Ulangan 6:4-9, menyerukan kepada Israel bahwa Tuhan itu Allah kita, Tuhan itu Esa. Kasihilah Tuhan Allahmu dengan segenap hatimu dan dengan segenap jiwamu dan dengan segenap kekuatanmu, serta perintah kepada orangtua dalam mengajar anak-anak mereka kepada firman Tuhan. Orangtua merupakan seorang guru PAK yang mengajar dan mendidik anak. Pengajaran firman kepada anak-anak merupakan keperluan bagi seorang guru karena tugas ini adalah perintah langsung dari Tuhan. McConville mengatakan bahwa pengajaran firman kepada anakanak bertujuan supaya mereka menyembah dan taat kepada Allah, supaya setiap generasi baru memahami kebenaran Allah dan mereka menerapkannya dalam kehidupan mereka, Pengajaran pendidikan bagi anak 
penting karena anak merupakan generasi penerus pendidikan itu dalam kehidupan mereka. ${ }^{29}$

Dalam Ulangan 6:7 menjelaskan bahwa guru mengajarkan anak secara berulang-ulang, membicarakannya apabila engkau duduk di rumahmu, apabila engkau sedang dalam perjalanan, apabila engkau berbaring, dan apabila engkau bangun. Ini berarti, guru diharapkan gigih dan tanpa mengenal lelah dalam mengajar anak, karena pengajaran PAK tidak terbatas waktunya, kapan dan dimanapun berada."Mengajarkan berulang-ulang" secara harafiah berarti "meruncingkannya", "mempertajamnya" guru dianjurkan supaya berusaha sekuat tenaga, dan dengan memakai segala keahlian yang ada supaya penyataan kehendak Allah dihayati oleh generasi mendatang. ${ }^{30}$ Artinya adalah guru sekreatif mungkin menggunakan segala potensi atau talenta yang ada untuk mengajar peserta didik. Tujuannya agar peserta didik memahami serta dapat menerapkan firman Tuhan dalam kehidupan mereka.

Dalam Yehezkiel 33:7-8, Guru PAK bertanggungjawab terhadap apa yang dia ajarkan serta lakukan dalam proses pendidikan. Oleh karena itu, menjadi seorang guru tidaklah mudah. Di dalam Yakobus 3:1 dikatakan: "Janganlah banyak orang di antara kamu yang mau menjadi guru; sebab kita tahu, bahwa sebagai guru kita dihakimi menurut hukuman yang lebih berat." Dengan jelas dapat melihat bahwa tugas sebagai guru merupakan tugas yang perlu menghadapi resiko dan kewajiban yang berat di hadapan Tuhan. Yehezkiel 33:7-8 menjelaskan tentang tugas Yehezkiel sebagai pengajar. Dia merupakan guru PAK bagi umat Israel. Tugasnya merupakan sebagai penjaga dan pemberita firman Tuhan. Dalam ayat 7 dikatakan, "Aku menetapkan engkau menjadi penjaga bagi kaum Israel. Bilamana engkau mendengar suara firman dari pada-Ku, peringatkanlah mereka demi nama-Ku." Teks

\footnotetext{
${ }^{29}$ Gordon McConville, Op.Cip, 207.

${ }^{30}$ I. J. Cains, Tafsiran Alkitab Kitab UIangan 111., (Jakarta: BPK Gunung Multa, 1997), 134135.
}

ini dengan jelas mengatakan bahwa guru PAK adalah seorang yang ditetapkan Allah dengan kata lain dia dipilih Allah sebagai pengajar firman bagi umat-Nya. Dengan demikian, membutuhkan kesungguhan kepada para pengajar Allah. ${ }^{31}$ Supaya mampu melaksanakan tugas yang berat dalam menjaga dan mengajar umat Tuhan.

Di dalam ayat 8 dikatakan "Aku akan menuntut pertanggungan jawab atas nyawanya dari padamu." Jelas bahwa Tuhan menuntut pertanggungan jawab terhadap perintah yang di lakukan kepada umat-Nya. Dengan demikian seorang guru PAK adalah seorang yang bertanggungjawab penuh dalam melaksanakan tugas panggilan ini. Maleakhi 2:6 menunjukkan bahwa Guru PAK adalah pengajar kebenaran. Kebenaran yang dimaksud adalah firman Tuhan. Dalam ayat 6 dikatakan: "Pengajaran yang benar ada dalam mulutnya dan kecurangan tidak terdapat pada bibirnya, Dalam damai sejahtera dan kejujuran ia mengikuti Aku dan banyak orang dibuatnya berbalik dari kesalahan." Dalam The Pickering Bible Commentary for to Day dikatakan bahwa sikap seorang pengajar adalah:Pertama, dia takut Tuhan, berdiri dan berpegang pada nama-Nya. Kedua, pengajaran yang benar keluar dari mulutnya; mengajar firman dengan tepat dan benar (Torat) NBD 'law'; DBT law . Ketiga, tidak terdapat kecurangan dalam perkataannya. Keempat,". dia berjalan bersama Allah dalam damai dan kejujuran yang terus menerus, hubungan yang erat dengan Tuhan, menikmatinya, dan taat pad janji Tuhan. Kelima, mengajar orang banyak berbalik dari kesalahan, membawa kepada kebenaran, kepada iman dan pengetahuan akan panggilan Yesus Kristus sebagai imam yang tinggi. ${ }^{32}$

Hal ini menunjukkan bahwa guru PAK adalah seorang pengajar kebenaran. Apa yang diajarkan sesuai dengan firman Tuhan

\footnotetext{
${ }^{31}$ Charles F. Pfeiffer and Everett F. Harisson, The Wycliffe Bible Commentary Old Testament. (Cichago: Moody Press, 1981), 750.

${ }^{32}$ W. Ward Casque, The Pickering Bible For to Day. General Editor G. C. D. Howley. (LondonGlasgow: Pickering dan Inglis, 1980), 1051.
} 
tanpa ada kecurangan dalam perkataannya. Karena itu guru PAK merupakan pengajar kebenaran dan juga sebagai pelaku kebenaran itu. Guru PAK merupakan seorang yang dipilih Allah. Oleh karena itu, dalam melaksanakan tugas sebagai pengajar tidak bersungut-sungut. Dalam ayat $6 \mathrm{~b}$ dikatakan: "Dalam damai sejahtera dan kejujuran ia mengikuti Aku dan banyak orang dibuatnya berbalik dari pada kesalahan." Artinya bahwa seorang guru PAK melaksanakan tugas dengan hati yang taat pada firman-Nya, tanpa ada unsur paksaan dari pihak lain. Tetapi dengan pengabdian yang mengasihi Tuhan.

Dalam Matius 7:28-29 dinyatakan bahwa pada waktu Yesus bersama-sama dengan murid-muridnya Dia biasa dipanggil atau disebut guru (rabi). Dalam Matius 26:18a dikatakan Jawab Yesus: "Pergilah ke kota kepada si Ami dan katakan kepadanya: Pesan Guru; waktu-Ku hampir tiba." Dengan jelas melihat bahwa bukan hanya muridmurid-Nya menyebut Dia sebagai guru tetapi Dia sendiri menyebut Diri-Nya sebagai Guru. Boehlke mengatakan bahwa kegiatan Yesus lebih digambarkan dengan kata kerja "mengajar" daripada kata kerja "memberitakan" atau "berkhotbah". Kata kerja tersebut condong dipakai justru karena Yesus betul-betul seorang guru, rabi dan kata benda "guru" itu melambangkan peranannya di tengah-tengah mereka selama jangka waktu sebelum la di salibkan. ${ }^{33}$

Jelas bahwa Yesus adalah seorang pengajar atau guru. Dalam kegiatan Yesus sebagai pengajar Dia juga disebut guru Agung yang memanggil jemaat untuk mengajar dan diajar. Lebih lanjut Robert mengatakan bahwa la bukan disebut guru Agung berdasarkan pembaharuan pengajaranNya melainkan hakikat pribadi-Nya sendiri. ${ }^{34}$ Artinya Yesus disebut sebagai guru Agung karena Yesus adalah Tuhan dan Juraselamat manusia.

Dalam Matius 7:28-29 dikatakan "Dan setelah Yesus mengakhiri perkataan ini,

33 Robert. R. Boehlke, Sejarah Perkembangan Pikiran dan Praktek Pendidikan Agama Kristen I. (Jakarta: BPK. Gummg Mulia, 2005), 61-62.

${ }^{34}$ Ibid., 64. takjublah orang banyak itu mendengar pengajaran-Nya, sebab la mengajar mereka sebagai orang yang berkuasa tidak seperti ahli-ahli taurat mereka." Artinya adalah Yesus sebagai guru mengajar, dengan otoritas-Nya. ${ }^{35}$ Otoritas Kristus menggugah dan mengubah hati pendengar-Nya yang mau mengikuti Dia.

Guru PAK adalah pengajar Firman. Oleh karena itu, seorang guru PAK mengajar dengan otoritas, agar firman yang disampaikan dapat mengubah hati mereka yang mendengar melalui kuasa Roh Kudus. Guru PAK dapat mengajar dengan otoritas Tuhan apabila dia taat kepada Tuhan sama seperti Yesus taat kepada Bapa-Nya. Dengan demikian guru PAK adalah guru yang mengajar dengan otoritas Kristus.

Di dalam Efesus 4:11 dikatakan, "Dan Ialah yang memberikan baik rasul-rasul maupun nabi-nabi, baik pemberita-pemberita Injil maupun guru-guru dan pengajarpengajar." Kalimat ini menjelaskan bahwa guru PAK merupakan pemberian Allah yang dianugerahkan kepada setiap orang pilihanNya sebagai guru. Ini berarti seorang guru PAK bukanlah seorang yang berambisi memiliki jabatan semata, melainkan karunia Allah kepada setiap guru yang telah Dia tetapkan.

Tugas sebagai guru adalah anugerah Tuhan. Andar Gultom dengan mengutip pendapat K.O, Gangel dalam bukunya Standar Kompetensi, dan Pengembangan Pnofesi Guru PAK, mengatakan bahwa mengatakan bahwa kekudusan dalam Alkitab ada kepada setiap orang Kristen. Tetapi kemampuan itu disalurkan kepada orang lain mengenai kebenaran yang bersumber dari Tuhan. Perkataan itu merupa-kan sebuah anugerah dalam pengajaran. Ini berarti tugas sebagai guru PAK merupakan pemberian

\footnotetext{
${ }^{35}$ Otoritas Kristus adalah kuasa Mesias yang Ilahi: Manusia-Allah, yang melakukan kehendak bapak-Nya dalam kedudukan-Nya yang rangkap (a) sebagai pelayan manusia yang dalam Diri-Nya pada jabatan nabi, imam, dan raja (b) sebagai anak Allah turut menciptakan segala sesuatu dan berperan dalam seturuh pekerjaan bapak.
} 
Allah, ${ }^{36}$ karena itu, hendaklah setiap guru PAK menyadari bahwa tugas sebagai pengajar adalah karunia dari Allah. Hal ini akan nyata kepada setiap guru PAK ketika menekuni bidangnya sebagai pengajar PAK dengan berpegang teguh pada perintah Tuhan. Dengan demikian guru PAK melaksanakan tugas sebagai pengajar firman Allah dengan sungguh-sungguh dan bertanggungjawab atas anugerah yang Tuhan berikan dengan ketekunan dan keteguhan hati atas setiap tugas yang dilimpahkan kepadanya.

Allah menganugerahkan karunia mengajar kepada setiap orang yang dikehendakiNya, dan seorang guru PAK seharusnya menyadari akan hal tersebut; yaitu bahwa ia yang telah ditetapkan Allah untuk mendewasakan jemaat Allah. Allah memilih pengajar-pengajar untuk pekerjaan pelayanan pembangunan tubuh Krisrus. Hoehner mengatakan bahwa dalam ke-daulatan Allah memberikan karunia untuk Gereja. Karunia ini dipakai bukan untuk kepentingan diri sendiri tetapi untuk membangun orang-orang kudus. ${ }^{37}$ Ini berarti, tugas ini diberikan untuk melayani umat Tuhan supaya bertumbuh di dalam tubuh Kristus dan kedewasaan iman dengan hanya bergantung penuh kepada Allah. Jadi, guru PAK adalah guru yang melaksanakan tugas ini demi kemuliaan Allah.

Guru PAK adalah guru yang membawa ajaran sehat. Dalam Titus 1: 9 dikatakan "Dan berpegang teguh kepada perkataan yang benar, yang sesuai dengan ajaran sehat, supaya ia sanggup menasihati orang berdasarkan ajaran itu dan sanggup meyakinkan penentang-penentangnya." Ayat ini berbicara 'dapat mengajar' (1 Tim. 3:2), dengan jelas menunjukkan tanggung jawab ini untuk mengurus dan mengajar jemaat. ${ }^{38}$

\footnotetext{
${ }^{36}$ Andar Gultom, Profestonalisme, Standar Kompetensi, dan Pengembangan Profesi Guru $P A K$, (Bandung: Bina Media Informasi, 2007), 33.

${ }^{37}$ Horald W. Hoehner, Ephesians An Exegetical Commentary. (Grand Rapids, Michigan: Baker Academic, 2004), 47.

${ }^{38}$ Knight, Op.Cip, 294.
}

Tugas mengajar ini terdiri dari tiga bagian yakni kesetiaan kepada ajaran dan pesan yang benar, mampu mengajarkannya kepada orang lain, dan mampu menunjukkan bahwa pendapat orang-orang yang menentangnya itu salah, ${ }^{39}$ Ini berarti seorang guru PAK merupakan seorang yang setia menuruti ajaran yang benar dan sesuai dengan ajaran Kristus. Dengan itu guru PAK akan mampu mengajarkan ajaran sehat dan mampu menegur orang-orang yang menentang ajaran Kristus. Dengan demikian guru PAK adalah guru yang mengajarkan ajaran Kristus serta menentang ajaran yang tidak sesuai dengan ajaran Kristus yaitu firman Allah.

\section{Tantangan Guru PAK}

Menurut Kamus Besar Bahasa Indonesia (KBBl) tantangan artinya hal atau objek yang menggugah tekad untuk meningkatkan kemampuan mengatasi masalah; rangsangan (untuk bekerja lebih gjat, dsb). ${ }^{40}$ Tantangan bukanlah hambatan melakukan pekerjaan tetapi tantangan merupakan motivasi mengerjakan sesuatu lebih baik lagi. Tantangan merupakan musuh besar setiap manusia. Keinginan manusia cenderung melepaskan diri dan tantangan dan mencari kepuasan diri sendiri. Oleh Karena itu, manusia terus bergumul memakai ber-bagai cara agar lepas dari tantangan. Akan tetapi, rancangan manusia bukanlah rancangan Tuhan. Tantangan sesuatu yang terus menerus ada dan perlu dihadapi, karena melalui tantangan kita mendapatkan janji Tuhan (Yak. 1:12).

Guru PAK berjalan dengan tantangan yang ada didepannya dan hal itu haruslah dijalani dengan penuh suka cita sebab melalui tantangan tersebut ia menjalani proses dan membentuk dan mengenali diri di hadapan Tuhan. Oleh karena itu, tantangan bukan musuh yang menghambat pekerjaan Tuhan tetapi tantangan yang membentuk hati

\footnotetext{
${ }^{39}$ Arichea dan Hatton, Op.Cip, 1277.

${ }^{40}$ Tim Penyusun KBBI Op.Cip, 1141.
} 
melakukan pekerjaan dengan bersungguhsungguh dan taat pada janji Tuhan.

\section{Pluralisme Agama}

Agama berkembang sebagai suatu organisasi, bahkan berbentuk institusi (lembaga) sesuai dengan tuntutan dari agama itu sendiri, dan juga perbedaan kepercayaan sesuai ajaran yang dianutnya, Hendropuspito mengatakan bahwa sekali agama masuk dalam system kelembagaan dan menjadi suatu hal yang rutin, maka agama itu akan mengahadapi kesulitan yang timbul dari rutinisasi itu. ${ }^{41}$ Akan tetapi bukan hanya kesulitan yang masih relatif mudah dicari jalan keluarnya, tetapi merupakan dilema. Lebih lanjut Hendropuspito mengatakan bahwa dalam dilema orang diperhadapkan dengan satu pilihan dari antara dua alternatif yang berlawanan antara ya dan tidak. Celakanya memilih 'ya' yang juga salah; memilih 'tidak' juga tidak benar. ${ }^{42}$ Ini disebabkan karena kurangnya pemahaman masyarakat mengenai ajaran yang dianut. Sehingga timbul sikap fanatisme. Inilah yang dihadapi masyarakat karena hidup ditengahtengah agama yang berbeda-beda ajarannya.

Seiring dengan itu guru PAK juga mengalami hal yang sama dalam melaksanakan tugasnya baik di sekolah negeri, swasta nasional atau di sekolah yang bukan lembaga Kristen. Gultom mengemuka-kan bahwa guru PAK dalam mengemban tugasnya dalam pembelajaran di sekolah mengahadapi tantangan pluralisme baik nilai, kepercayaan dan spiritulitas. ${ }^{43}$ Tidak mudah bagi seorang guru PAK berinteraksi dan menyampaikan pembelajaran PAK di tengah perbedaan kepercayaan ini. Masalah adalah bagaimana guru PAK berinteraksi dengan masyarakat dan peserta didik yang berbeda kepercayaan.

Dari pengamatan penulis dapat diketahui bahwa masing-masing agama mempertahan-kan identitas sebagai agama

\footnotetext{
${ }^{41}$ D. Hendropuspito, (Jakarta: BPK Gunung

Mulia, 2006), 127.

${ }^{42}$ Hendropuspito, Op.Cip,

${ }^{43}$ Gultom, Profesionalisnie. Op.Cip, 45.
}

yang baik. Dalam buku Pendidikan Agama Kristen dikatakan bahwa pemahaman seperti ini melahirkan sikap saling curiga yang cukup merugikan. Pada akhirnya muncul konflik agama yang biasanya disertai kekerasan dan dendam. ${ }^{44}$ Begitu juga dalam dunia pendidikan masing-masing berusaha mendirikan sekolah sebagai tempat mengajarkan ajarannya. Sebuah kenyataan inilah yang sedang terjadi dan mengakibatkan persaingan ketat, baik secara kuantitas terlebih-lebih kualitas.

Merupakan sebuah beban dan tantangan guru PAK, bagaimana seperlunya membawa diri di tengah-tengah dilema yang sedang terjadi. Suatu tuntutan bagi para PAK, bagaimana bisa bangkit, dan menjadi teranglah ditengah kegelapan dunia (Yes. 60:1). Di sisi lain perbedaan agama ini menjadi peluang untuk memberitakan Injil. Ini juga bukan hanya kepada guru PAK tetapi semua yang mengaku murid Kristus mempunyai tanggung jawab ini. Tetapi sebuah harapan murid jikalau hal ini menempuh dengan iman kepada Yesus maka dengan yakin Tuhan berkenan.

\section{Motivasi Upah}

Secara etimologi motivasi berasal dari kata "moti vare" (bahasa latin), yang berarti menggerakkan atau mendorong, dan dalam percakapan sehari-hari, istilah motivasi sering disebut sebagai dorongan kemudian dari sudut pandang psikologis, motivasi merupakan kondisi atau keadaan psikis seorang yang mendorong dia untuk melakukan sesuatu ke arah pencapaian tujuan. ${ }^{45}$ Ini berarti motivasi adalah proses dorongan, arahan dan pemeliharaan perilaku kearah suatu sasaran atau tujuan yang hendak dicapai dengan jelas. Dengan kata lain perilaku yang diarahkan atau tujuan yang jelas.

\footnotetext{
${ }^{44}$ Jason Lase (Editor), Pendidikan Agama Kristen. (Bandung: Bina Media Infoimasi (BM I), 2005), 148.

${ }^{45}$ Ngalim Purwanto, Psikologi Pendidikan, (Jakarta: Remaja Rosdakarya, 2006), 73.
} 
Dalam dunia pendidikan guru merupakan unsur penting. Baik dalam mengajar maupun dalam mendidik peserta didik. Akan tetapi, guru melaksanakan tugas mengajar dengan tujuan kepentingan diri sendiri. Guru hanya mementingkan upah dalam melaksanakan tanggung jawabnya sebagai pengajar. Guru mengajar ketika tunjangannya besar. Sehingga guru memikirkan bagaimana gajinya semakin besar tanpa pengabdian secara sungguh-sungguh melaksanakan tugas mengajarnya.

Ada beberapa Guru yang mengajar karena termotvasi oleh unsur-unsur lain, misalnya untuk mendapat pekerjaan (tidak pengangguran). Dampak dari pemikiran guru yang demikian mengaburkan anugerah Allah bagi dirinya dalam mengajar. Sehingga guru mengajar hanya asal-asalan tanpa kesungguhan hati, berpegang teguh, dan berpengharapan bahwa Tuhan akan mencukupkan kebutuhan kita dan pekerjaan tugas mengajar tidak sia-sia (1 Kor. 15:58). Oleh karena itu guru PAK adalah guru yang mengajar karena panggilan dan karunia dari Allah tanpa unsur materi. Jadi, sekalipun guru PAK membutuhkan gaji tetapi bukanlan prioritas utama melakukan tugas mengajar, melainkan hati yang mau melayani Tuhan.

\section{Perkembangan IPTEK}

Perkembangan Ilmu Pengetahuan dan Teknologi (IPTEK) merupakan sesuatu yang nyata dan terus-menerus meningkat dan berubah dan juga zaman yang terus berubah. Kita menyadari bahwa kemajuan ilmu pengetahuan dan teknologi disatu segi membawa keberuntungan bagi kehidupan manusia. Di mana dapat menolong dan memudahkan serta mempercepat pekerjaan. Akan tetapi, upaya mengajar dan memberi perhatian besar bahkan berlebihan kepada penemuan-penemuan modern serta teknologi. Sidjabat mengatakan bahwa IPTEK hasil yang membuat orang lupa akan penekanan keutamaan dan kebijaksaan hidup dalam melaksanakan panggilan hidup sehari-hari. ${ }^{46}$ Artinya kehadiran IPTEK dalam dunia pendidikan disalahgunakan di mana perhatian utama pada semua bahan yang ada, karena berkembanganya perhatian pendidikan pada teknologi pengajaran sekarang ini, membuat banyak calon pendidik lebih menekankan segi-segi teknik dan metode praktis dalam tugas mengajar.

Sidjabat mengutip pendapat Tondowidjojo mengemukakan bahwa sisi dasar yang tetap diperlukan guru sejarang ini ialah keutamaan hidup guru itu sendiri, "Di dalam hidup kita sehari-hari keutamaan kebijaksanaanlah yang menjadi kunci bagi penerapan sikap yang tepat dalam situasi dan kondisi yang kita hadapi. ${ }^{47}$ Lebih lajut Sidjabat mengatakan bahwa keutamaan yang dibicarakannya antara lain ialah ketetapan, stabilitas, menegur dengan sopan, mawas diri, kesabaran, kesederhanaan, menghargai profesi, berprasangka yang baik, mengontrol kompetensi, memikirkan masa depan, humor yang sehat, ketenangan, melaksanakan tugas dengan baik membuat persiapan yang baik, dan memiliki semangat iman. ${ }^{48}$ Karena itu, IPTEK bukanlah segala-galanya bagi guru tetapi merupakan penolong mempermudah dan memperjelas bahan pelajaran kepada peserta didik. Keutamaan hidup akan menentukan keberhasilannya sebagai pengajar karena membawa kepada pengenalan diri dan tujuan mengajar yang sebenarnya dihadapan Tuhan.

\section{Kualifikasi Guru Pendidikan Agama Kristen Berdasarkan Pengajaran Paulus Terhadap Timotius}

\section{Aspek Rohani (Spiritual)}

Pertama, Iman. Kristus tinggal di dalam dia (Yoh. 15:4). Dalam ensiklopedi Alkitab (A:I) dinyatakan bahwa iman adalah sikap yang di dalamnya seseorang melepaskan andalan pada segala usahanya

\footnotetext{
${ }^{46}$ Sidjabat Op.Cip, 30.

${ }^{47}$ SidjabaT, Op.Cip, 31.

${ }^{48}$ Ibid., 32
} 
sendiri untuk mendapatkan keselamatan, entah itu kebajikan, kebaikan sosial, atau apa saja, kemudian sepenuhnya mengandalkan Yesus Kristus, dan mengharapkan hanya diri Dia segala sesuatu yang dimaksud oleh keselamatan. ${ }^{49}$ Jadi beriman berarti menyerahkan diri sepenuhnya kepada Yesus dan bergantung hanya kepada Dia, karena ialah jalan satu-satunya keselamatan manusia. Jadi iman merupakan sebuah tindakan yang sedang terjadi dalam hidup orang yang percaya.

Berkhof menjelaskan bahwa iman, keteguhan, kepercayaan adalah pertama, suatu kepastian berdasarkan kepercayaan dalam diri seseorang dan pengakuannya yang berbeda dengan pengetahuan bersandar penelitian pribadi. Kedua, rasa percaya diri untuk diri itu sendiri dimana kepercayaan seseorang bersandar. ${ }^{50}$ Penjelasan di atas menyatakan bahwa subjek iman merupakan keteguhan, pendirian kepercayaan atas kebenaran dan objek atau pelaku iman merupakan setiap orang yang percaya menerima dengan iman dan kebenaran.

Pemahaman Paulus tentang iman adalah sikap khas seorang Kristen. Dalam Roma 1: 16, Paulus berkata bahwa injil adalah kekuatan Allah yang menyelamatkan setiap orang percaya. ${ }^{51}$ Artinya injil tidak hanya menyatakan kepada manusia tentang apa yang wajib mereka lakukan, tetapi juga memberi kekuatan kepada mereka untuk melakukannya. Iman yang dimasksudkan Paulus adalah iman yang memberi kekuatan. Kata "iman" adalah kekuatan yang dimiliki oleh seorang militer yang kuat dalam melakukan peperangan, kata ini ditunjukkan pada Timotius dalam menunaikan tugas panggilannya. Dia tetap kuat seperti tentara yang rela menyerahkan nyawanya demi mempertahankan dan meraih sebuah kemenangan.

Paulus menggunakan istilah miler kepada Timotius untuk menekankan pernyataannya mengenai kata "tugas" (I Tim. 1:10). Ini berarti suatu perintah yang

\footnotetext{
${ }^{49}$ Doungles, Op.Cip, 430-431.

${ }^{50}$ Louis Berkhof, Op.Cip, 121.

${ }^{51}$ Douglas, Op.Cip, 1315.
}

mendesak yang diteruskan oleh atasan tertinggi. Maksudnya adalah Paulus telah memerintahkan Timotius untuk tinggal di Efesus dan mengajarkan ajaran sehat (I Tim. 1:3). Tidaklah mudah melayani jemaat yang ada di Efesus, karena penuh dengan penyembah berhala. Tetapi Timotius seorang yang mendapatkan perintah dan perlu menaati perintah itu. Hal ini menunjukkan sebuah tugas yang membutuhkan kerja keras memperjuangkan perjuangan dengan baik. Dengan demikian, beriman berarti memiliki kekuatan dengan keyakinan kepada Yesus.

Kedua, Hati Nurani (1 Tim. 1:10). Hati "nurani" artinya pengetahuan ini dipegang dalam diri sendiri. Menurut Vaughan, kecakapan untuk pengetahuan bersama dengan diri sendiri (Romans, 1886, hlm.40). ${ }^{52}$ dengan demikian, hati nurani dapat diartikan sebagai pengetahuan yang ada dalam diri seseorang. Kata "hati nurani" yang dipakai dalam ayat 18 , adalah merupakan objek. Dalam hal ini Timotius sebagai objek yang berarti seorang tentara dan ini juga berkaitan dengan pelaksanaan tugas yang diberikan kepada Timotius.

Kata "hati nurani" dalam King James Version (KJV) menerjemahkan a good warfare (sebuah peperangan yang baik), "memperjuangkan perjuangan yang baik". Dan juga dalam New Internasional Version (NIV) menerjemahkan The good fight (berjuang dengan baik). ${ }^{53}$ Dalam surat Paulus kepada Timotius dan kepada Titus dinyatakan bahwa: "Ungkapan ini diambil dari istilah ketentaraan dan dipakai sebagai kiasan untuk membandingkan tugas Timotius dengan tugas yang dihadapi tentara dalam peperangan. Di bagian Perjanjian Baru lainnya, ada pernyataan mengenai peperangan melawan kejahatan, terutama iblis dan kejahatan dalam diri kita sendiri, bukan peperangan secara fisik melawan orang lain. Dalam konteks ayat ini perjuangan yang dimaksud adalah perjuangan melawan para

\footnotetext{
${ }^{52}$ Ibid, 37.

${ }^{53}$ Hasan Sutanto, Perjanjian Baru Interlinear Kunani Indonesia dan Konkordinasi Perjanjian Baru (PBIK), Jilid II, Jakarta, LAI : 2004), 720.
} 
pengajar sesat yang mengajarkan ajaranajaran yang bertentangan dengan injil " . .4

Perjuangan Timotius bukan berperang secara fisik atau daging, tetapi berperang melawan ajaran-ajaran yang telah berkembang dijemaat yang bertentangan dengan injil. Perjuangan yang baik ini memurnikan ajaran-ajaran sesat dengan injil. Melawan kejahatan dalam diri dan iblis, juga merupakan hal penting yang sering diabaikan dalam diri setiap pelayan Tuhan. Dalam Matthew Henry's Commentary dinyatakan bahwa the ministry is a good warfare against sin and satan. Ministers must war this good warfare diligently and courgeowsly. ${ }^{55}$ Penjelasan di atas menyatakan seorang pelayan berperang dengan baik melawan dosa dan setan. Seorang pelayan perlu berperang dengan perjuangan baik dengan rajin dan berani. Hal ini menunjukkan bahwa melawan dosa dan setan merupakan keperluan bagi seorang pelayan Tuhan, karena walaupun melayani Tuhan dengan sekuat tenaga, tetapi tidak bisa mengontrol diri dari dosa, maka semuanya sia-sia. Oleh karena itu, melawan dosa dan setan merupakan hal penting bagi seorang pelayan Tuhan.

"Hati nurani" juga diungkapkan dalam beberapa istilah seperti "suara kecil, atau orang kecil yang ada di dalam hati", "bayangan di dalam diri", "gema hati", "batin" atau "hati". Istilah ini menggambarkan bagian batin seseorang yang memperingatkannya tentang perilaku yang baik maupun nilai-nilai moral atau kemampuan orang untuk membedakan antara benar dan salah. ${ }^{56}$ Pengertian tersebut menunjuk kepada kesungguhan diri seseorang dalam melaksanakan tugas seperti apa yang diperintahkan Tuhan melalui rasul Paulus kepada Timotius "fight to the good fight (ware the good warfare) holding on to faith

\footnotetext{
${ }^{54}$ Archea dan Hatton, Op.Cip, 37.

${ }^{55}$ Matthew Henry, Matthew Henry's Comentary In One Volume. (Singapore: $\mathrm{S}+\mathrm{U}$ Publisher, 1982), 88.

${ }^{56}$ Arichea dan Hatton, Surat Paulus Kepada

Timotius dan Kepada Titus, 37.
}

and a good conscience?. ${ }^{57}$ Ini bermaksud Timotius dalam melaksanakan tugas berjuang dengan baik, memegang iman dan hati nurani. Paulus telah banyak memperhatikan dia dan dengan hati yang murni sebagai teman sekerjanya dan juga beberapa di antara mereka (jemaat) telah menolong dia dari keburukan iman mereka.

Dengan demikian, iman dan hati nurani merupakan hal penting dalam melakukan tugas panggilan. Karena me-nyangkut hubungan dengan Tuhan yang didasarkan pada keyakinan yang kokoh pada Injil-Nya dan hati nurani membawa kepada kerja keras (rela menyerahkan nyawa-Nya) demi mengabdi kepada Allah dengan melaksanakan tugas yang di emban.

Ketiga, Ibadah. Kata "ibadah" adalah kesolehan. Maksud kesolehan disini adalah hidup yang berkenan kepada Allah. Budiman menyatakan hidup yang berkenan kepada Allah adalah hidup dengan penghayatan iman dalam kata-kata dan perbuatan. ${ }^{58}$ Itu berarti, kesalehan diekspresi melalui kata-kata dan perbuatan yang benar sebagai wujud iman kepada Yesus Kristus.

Dalam Word Study Dictionary dinyatakan bahwa ibadah dipakai untuk kehidupan orang Kristen yang menunjukkan hidup yang menerima Kristus, menandakan sebuah sikap yang layak sebagai orang yang percaya kepada Kristus yang menyelamatkan dia. ${ }^{59}$ Oleh karena itu, ibadah merupakan sebuah sikap baik kata-kata maupun perbuatan yang layak dihadapan Tuhan. Lebih lanjut Zodhiates menjelaskan bahwa godliness refers to the simple worship of the believer. ${ }^{60}$ Di sini penulis melihat bahwa ibadah menunjuk pada sikap dan penyembahan yang berkenan kepada-Nya merupakan salah satu ciri seorang Kristen sejati. Karena sikap menyatakan kesalehan seseorang yang diekspresikan kepada orang lain, dan

\footnotetext{
${ }^{57}$ Ralph Earle, The expositor's Bible commentary, General editor Franc E. Gaebelein. (Grand Rapids, Michigan: Zondervan Publishing House, 1984, 367.

${ }^{58}$ Budiman, Op.Cip, 63.

${ }^{59}$ Spiros Zodhiates, Op.Cip, 638.

${ }^{60}$ Ibid.
} 
penyembahan menyatakan hubungan pribadi dengan Tuhan. Ibadah adalah cara hidup yang menurut kehendak Allah dan sesuai dengan pedoman iman Kristen. Haak menegaskan bahwa ibadah adalah seluruh hidup perlu dipersembahkan sebagai korban syukur kepada Allah dengan dipenuhi oleh kehendak Allah dengan merenungkan firman-Nya dan berdoa. ${ }^{61}$ Ini berarti dalam keseharian hidup seorang guru PAK tidak berhenti menyadari bahwa seluruh hidupnya dijalani di dalam hadirat Tuhan. ${ }^{62}$ Dengan demikian, ibadah merupakan sikap saleh yang berkenan kepada Tuhan, dan juga merupakan persekutuan pribadi dengan Tuhan.

\section{Aspek Kognitif}

Guru PAK merupakan seorang komunikator kebenaran Allah. Mengajar merupakan tugas yang penting bagi seorang guru PAK, karena melalui pengajaran pandangan dunia dan ajaran-ajaran yang benar dapat disampaikan kepada peserta didik, sekaligus dapat menangkal informasi yang tidak benar dan ajaran-ajaran yang menyesatkan (1 Pet. 5:3) ${ }^{63}$ Oleh karena itu, guru PAK perlu memiliki pengetahuan yang berkualitas dalam mengemban tugas panggilan pelayanan.

Pertama, Cakap Mengajar (3:2). Mengajarkan firman Allah adalah salah satu pelayanan utama dari seorang guru PAK. Oleh karena itu, seorang pengajar PAK perlu memiliki kecakapan untuk mengajar orang lain. "Cakap mengajar" merupakan yang dimiliki seorang dalam mengajar orang lain. Dalam The New International Greek Testament Commentary (NIGTC) dikatakan bahwa cakap mengajar adalah skillful in

\footnotetext{
${ }^{61}$ Haak, 1 Op.Cip, 15.

${ }^{62}$ Barclay, Op.Cip,. 209-230.

${ }^{63}$ Dien Sumiyatiningsih, Mengajar Dengan Kreatif \& Menarik. (Yogyakarta : ANDI Offset, 2007), 162.
}

teaching (BAGD) ${ }^{64}$ Artinya keterampilan atau kemahiran dalam mengajar. Pasal 3:2 ini merupakan paralel dari Titus 1:9, dimana setiap pengajar bertanggung jawab atas setiap pengajarannnya. Oleh sebab itu, cakap mengajar merupakan mahir, tangkas dalam pengajaran (menguasai bahan pelajaran), dimana bertanggung jawab dan menyampaikan ajaran Kristen dan menolak ajaran yang bertentangan. ${ }^{65}$ Dengan demikian, cakap mengajar dapat diartikan penguasaan bahan pengajaran dan juga penguasaan diri dalam mengajar supaya tidak menyimpang dari kebenaran firman Tuhan.

Dalam The Expositor's Bible
Commentary dikatakan bahwa cakap
mengajar "not merely a readiness to teach is implied, but the spiritual power to do so as the out come of prayerful medition in the word of God and the Practical application of its truth to oneself. ${ }^{66}$ Dari penjelasan ini dengan jelas cakap mengajar bukan hanya kesiapan penuh dalam mengajar yang dibutuhkan, tetapi kuasa Roh dalam melakukan pekerjaan sebagai hasil dari perenungan Firman Allah dan mengaplikasikan kebenaran itu kepada setiap pribadi pengajar. Itu berarti, hubungan pengajar dengan Tuhan sangat penting. Oleh karena melalui perenungan firman Allah dapat membangun kerohanian pengajar untuk lebih mem-persiapkan diri dalam mengajar sesuai dengan pimpinan dan kuasa Tuhan. Berkaitan dengan pengertian cakap mengajar di atas, dalam buku Calvin's New Testament Commentaries dikatakan bahwa: Tidak cukup kepada seseorang menjadi unggul dalam pengajaran, juga bukan melalui sebuah talenta untuk mengajar. Atau juga karena ungkapan yang kurang baik atau mental yang buruk atau karena mereka tidak bisa mengajar dengan baik, memelihara pengetahuan seorang yang berkuasa menunjukkan syarat seorang pengajar atau juga permintaan karena mereka fasih berbicara atau melihat banyak

\footnotetext{
${ }^{64}$ BAGD adalah A Greek English Lexicon of the New Testament and other Early Christian Literature

${ }^{65}$ Knight, Op.Cip, 158.

${ }^{66}$ Earle, Op.Cip,. 364.
} 
perubahan yang terjadi dalam diri mereka. Paulus mempercayakan hikmat dalam memahami firman Tuhan sehingga menjadi berkat bagi umat-Nya. ${ }^{67}$

Berarti tuntutan bagi seorang pengajar adalah mengajar dengan nikmat Tuhan melalui firman. Karena dengan hikmat dari firman, pengajar dapat mengetahui kehendak Allah terhadap pengajaran yang akan disampaikan. Menurut Henry bahwa cakap mengajar merupakan able and willing to communicate to others the knowledge with God has given him. ${ }^{68}$ Penjelasan di atas seorang yang cakap mengajar artinya seorang yang mampu dan dengan sikap sedia berkomunikasi kepada yang lain dengan pengetahuan yang Allah berikan kepada dia. Ini berarti, cakap mengajar merupakan seorang yang mempergunakan pengetahuan yang berasal dari Allah di dalam mengajar orang lain. Hal ini menunjukkan seorang pengajar yang mengajar dengan hikmat yang dari Allah. Dengan demikian pengajar yang cakap adalah pengajar yang mempergunakan hikmat Allah dalam pengajarannya.

Kedua, Ajaran Sehat (1 Tim 1:10). Surat Paulus kepada Timotius dan juga kepada Titus, tampaknya ditulis pada suatu kerangka pengajaran Kristen yang menjadi dasar untuk menentukan apakah suatu pegajaran atau kepercayaan tertentu itu sah dan bisa diterima. Maksudnya sah dan bisa diterima adalah pengajaran yang sesuai dengan pemberitaan para rasul. Itu sebabnya, Paulus menasehatkan Timotius tetap mempertahankan dan mengajarkan ajaran sehat kepada umat Tuhan di Kota Efesus.

Kittel mengatakan bahwa, mengajar berkaitan dengan dua aspek, yakni pengetahuan bagi seorang yang di ajar dan pengetahuan yang disampaikan oleh pengajar sebagai jembatan pengetahuan dan ke-

\footnotetext{
${ }^{67}$ Jhon Calvin, New Testament Commentaries The Second Epistle of Paul To The Corinthians, and the Epitles To Timothy. Titus and Philemon. (Grand Rapids, Michigan: Wm. B. Eardmans Publishing Company, 1980), 225.

${ }^{68}$ Henry, Matthew Henry Op.Cip, 1889.
}

mampuan bagi seorang murid. ${ }^{69}$ Artinya bahwa ketika Timotius (pengajar) memberikan pengajaran kepada umat Allah bukan saja untuk pengetahuan belaka tetapi tujuannya supaya umat Tuhan mampu menerapkan dalam kehidupan mereka mengenai pengetahuan yang diterima.

Istilah kata sehat atau dengan kombinasi ajaran atau perkataan adalah salah satu ciri khas dari Surat Pastrol (bnd. 1 Tim. 6:3:2 Tim. 1:13:4:3: Titus 1:9; 13; 2:1, 2,8). Ajaran sehat menggambarkan suatu kerangka pengajaran yang benar, tepat dan serta membina jemaat. Ajaran sehan juga merupakan salah satu kata kunci dari surat pastoral. Di tengah pergumulan hidup yang penuh dengan perjuangan, Paulus me-nasihatkan Timotius untuk melawan ajaran yang bertentangan dan mengajarakan ajaran sehat. Dalam Calvin's New Testament Commentaries dikatakan bahwa ajaran sehat adalah ajaran yang bertentangan, dari perkataan yang tidak berguna, pengajaran yang membawa kebohohan dan mem-bahayakan. ${ }^{70}$ Maksud Paulus ajaran sehat adalah ajaran tentang Injil dari Allah yang mulia (1 Tim 1: 11). Inilah tugas Timotius mengajarkan ajaran sehat yaitu Injil dari Allah kepada umat.

\section{Aspek Afektif}

Kata "Teladan" dalam ayat 12 adalah sebuah teladan moral. Barclay menjelaskan kata teladan adalah pola, contoh, patokan, itu berarti Timotius menjadi titik sentral untuk memberikan teladan atau pola yang baik bagi orang-orang percaya. ${ }^{71}$ Dalam dunia Yunani kata teladan menunjukkan sebuah proses kedudukan dan bentuk perilaku yang menghubungkan kedudukan dengan bentuk perilaku diri sendiri. Di dalam Exegetical Dictionary of The New Testament dinyatakan

\footnotetext{
${ }^{69}$ Gerhard Kittel, Theological Dictionary of the New Testament (TDNT) vol. II (Grand Rapids: Wm. B. Eardmans Publishing Company, 1980), 135.

${ }^{70}$ Calvin. Op.Cip, 194.

${ }^{71}$ Barclay, Op.Cip, 176.
} 
bahwa pengertian dasar mengenai teladan adalah merupakan suatu perkembangan dari yang konkrit kepada yang abstrak, dimana teladan datang menjadi kebiasaan dari berbagai gaya hidup yang mempengaruhi orang lain. ${ }^{72}$

Teladan Timotius merupakan suatu keperluan dalam melaksanakan tugas panggilannya, karena melalui teladan hidup yang baik membawa terang bagi orang-orang yang telah menyimpang dari firman Tuhan. Dengan demikian, keteladanan pengajar merupakan salah satu syarat mutlak dalam melaksanakan tugas panggilan pelayaan. Oleh karena itu, aspek-aspek sikap keteladanan yang perlu dimiliki oleh guru PAK adalah sebagai berikut:

Pertama, Perkataan (1 Tim. 4:12). Kata "Perkataan" adalah mengucapkan sesuatu, berpidato, mengemukakan sesuatu di dalam percakapan. Dengan demikian perkataan merupakan sesuatu yang dilakukan Timotius dalam pelayaannya. Dalam hal ini Timotius perlu menjadi teladan pada setiap perkataan yang dikeluarkan melalui percakapan pada orang percaya. Oleh karena itu Timotius dituntut kehati-hatian dalam berkata-kata agar tidak menyimpang dari Firman Allah. Menurut Balz mengatakan bahwa salah satu karakteristik serta pastoral adalah perkataan yang benar dan patut diterima $\left({ }^{73} 1\right.$ Tim. 1:15;3:1, 4:9 ; 2 Tim. 2:11; Tit. 3:8), berhubungan dengan pemberitaan para rasul, peribadatan, dan tempat per-sekutuan dalam iman tentang Yesus Kristus. Perkataan Timotius berhubungan dengan iman dalam kesetiaan mewartakan Injil. Di waktu tertentu merupakan percakapan sehari-hari melalui mulut (peh) menjadi sebuah perkataan. ${ }^{74}$

Menurut Paulus "perkataan" merupakan salah satu hal bagian dasar karena melalui perkataan seorang dapat berkomunikasi kepada orang lain. Dalam New International Greek Testament Commentary

\footnotetext{
${ }^{72}$ Horst Balz and Gehard Schenide (ed), dalam Exegetical Dictionary of The New Testament Vol. 3, (Grand Rapids, Michigan: William B.

Eardmans Publishing Company, 1994), 373.

${ }^{73}$ Balz and Scheneider, Op.Cip, 59.

${ }^{74}$ Lawrence O. Richards, Op.Cip, 633.
}

dikatakan bahwa of word memperlihatkan sebuah dasar dari kualitas dengan kasih, kesetiaan dan kemurnian. ${ }^{75}$ Arichea dan Hatton berpendapat bahwa perkataan harfiahnya "kata" dan menunjuk kepada percakapan pada umumnya. ${ }^{76}$ Itu berarti, perkataan yang dimaksudkan Paulus pada Timotius bukan hanya saat memberitakan Injil tetapi menyangkut semua perkataan di saat melakukan percakaan kepada orang lain.

Kedua, Tingkah Laku. Dalam New International Greek Testament Commentary dikatakan bahwa "tingkah laku" diartikan sebagai cara hidup, perbuatan. ${ }^{77}$ Dalam pemakaian kata ini lebih cocok digunakan pada orang Kristen yang menggambarkan kehidupannya. Baumgarten mengatakan bahwa tingkah laku menyatakan seluruh total hidup seseorang atau dia dalam berbagai ajaran agama atau dalam iman Kristen ${ }^{78}$. Dalam Surat 1 Timotius tingkah laku merupakan sebuah dasar akan pernyataan perkataan, kasih, iman, dan kemurnian yang menunjuk kepada seorang pimpinan jemaat (1 Tim. 4:"12) lebih umumnya dalam 1 Timotius 3:15.

Dalam Exegetical Dictionary of the New Testament dikatakan bahwa dalam tradisi Yahudi para pemimpin dihadirkan sebagai teladan yang oleh iman dapat ditiru dan yang keluar dari hidup mereka sebagai teladan. Cara hidup datang dengan iman dan ungkapan yang tampak sebagai seorang pemimpin Kristen. ${ }^{79}$ Lebih lanjut Baumgerten berpendapat mengenai tingkah laku, yakni: Pertama, tingkah laku merupakan sebuah cara hidup yang baik (1 Pet. 2:12). Hal yang sama dari penafsiran 1 Petrus ada selama waktu dalam percobaan kehidupan Kristen sebagai "aliens and exiles" (orang-orang asing dan orang-orang buangan) 1 Pet 2:11, 12. hal ini merupakan

\footnotetext{
${ }^{75}$ Knight, Op.Cip, 206.

${ }^{76}$ Arihea Op.Cip, 97.

${ }^{77}$ Knight, Op.Cip, 206.

${ }^{78}$ Horst Balz and Gehard Schenide (ed), dalam Exegetical Dictionary of The New Testament Vol.I, (Grand Rapids, Michigan: William B. Eardmans Publishing Company, 1994), 93. 79 Ibid, 8.
} 
nasehat atas tingkah mereka sendiri dalam "holiness and fear". Kekudusan dan ketakuatan sebagai dasar panggilan kudus dari Allah 91 Pet. 1:15). Kedua, di sisi lain tingkah laku merupakan sebuah norma hidup yang tampak kepada orang lain 2 Pet. 2:7. ${ }^{80}$ Archea dan Hatton lebih lanjut mengatakan bahwa tingkah laku merupakan sikap hidup yang di tampilkan kepada orang lain. ${ }^{81}$ Dengan demikian, tingkah laku menyangkut seluruh cara hidup seseorang yang tampak kepada orang yang untuk bisa diteladani.

Ketiga, Kasih. Perlu dipahami bahwa kasih adalah kekuatan dari dalam (UI 6:5 "Kekuatan") yang mendorong untuk melakukan suatu tindakan yang mendatangkan kegembiraan (Ams. 20:13), memperoleh objek yang membangkitkan hasrat (Kej. 27:4) atau dalam hal pribadi untuk melakukan pengorbanan diri demi kebaikan orang yang dikasihi (Im. 19:18,34) dan ketaatan yang tulus (1 Sam. 20:17-42). Kasih dalam Perjanjian Baru secara etomologi adalah agape. Kata itu berarti kasih yang paling tinggi dalam paling mulia, yang melihat suatu nilai yang tak terbalas pada objek kasihnya. ${ }^{82}$ Istilah agape menjadi terkenal karena ia merupakan salah satu dari istilah kasih yang dijabarkan dalam Perjanjian Baru.

Dalam hal ini Timotius adalah sumber kasih tersebut dalam melaksanakan tugas panggilannya, oleh karena itu merupakan hal yang penting dalam melaksanakan sebuah tugas. Schneider mengatakan bahwa tujuan dari perintah ini adalah kasih dalam sebuah hati nurani dan iman yang tulus (1 Tim. 1:5). ${ }^{83}$ Archea dan Hatton mengatakan bahwa maksud kasih di sini adalah kasih yang ditunjukkan kepada orang lain, terutama anggota jemaat yang percaya. $^{84}$ Lihat

\footnotetext{
${ }^{80}$ Balz and Scheneider, Op.Cip, 93.

${ }^{81}$ Arichea dan Hatton, Op.Cip, 97.

${ }^{82}$ Douglas, Op.Cip,.532.

${ }^{83}$ Horst Balz and Gehard Schenide (ed), dalam Exegetical Dictionary of The New Testament Vol.I, (Grand Rapids, Michigan: William B. Eardmans Publishing Company, 1994), 11. ${ }^{84}$ Arichea dan Hatton, Op.Cip, 97.
}

BIMK $^{85}$ (dalam cara engkau mengasihi sesama). "Kasih" menggambarkan kualitas pelayanan seseorang. Knight mengatakan bahwa dalam segala sesuatu dilakukan dengan kasih (Kol. 3:14) dan kasih yang sama seperti Kristus mengasihi jemaat. Kasih merupakan suatu mutu brsifat menentukan sebuah hidup orang Kristen ( $\mathrm{Rm} \mathrm{12:9;} \mathrm{13:9,}$ 10; 1 Kor. 8:1; Gl. 5:6,13, Flp. 2:12). ${ }^{86}$

Keempat, Kesetiaan (1 Tim. 4:12). Dalam kamus Besar Bahasa Indonesia kata kesetiaan artinya keteguhan hati, ketaatan. ${ }^{87}$ Dengan demikian kesetiaan dapat berarti ketulusan hati melaksanakan tugas yang dipercayakan dengan prinsip ketaaatan dan keikhlasan melakukan tugas.

Kata 'Kesetiaan" adalah sikap percaya diri, bukan keragu-raguan. Berarti kesetiaan merupakan kepercayaan diri (self confidence) pada suatu yang di harapkan dan imani. Blaiklok mengatakan bahwa maksud kesetiaan dalam ayat ini merupakan keteguhan hati dan ketetapan dalam memegang keyakinan. ${ }^{88}$ Memegang keyakinan yang dimaksud adalah keyakinan di dalam Yesus sebagai sentral iman Kristen. Arichea dan Hatton mengemukakan bahwa kesetiaan merupakan panduan dari kepercayaaan serta keyakinan terhadap Yesus Kristus, dan juga kesetiaan kepada-Nya. ${ }^{89}$

Kesetiaan bukanlah langkah atau perbuatan awal dalam sikap percaya kepada Allah, tetapi merupakan perbuatan yang terjadi sebagai akibat karena percaya. Hendriksen mengemukakan bahwa iman merupakan pemberian Allah yang merupakan akar dari kasih, dimana kasih menunjukkan hubungan terhadap sesama, dan iman menunjukkan dengan Tuhan. ${ }^{90}$

Kelima, Kesucian. Paulus menasehatkan Timotius supaya menjaga kesucian dalam menjalankan tugas. Arti kesucian atau

\footnotetext{
${ }^{85}$ BIMK adalah Alkitab dalam Bahasa Indonesia Masa Kini

${ }^{86}$ Knight, Op.Cip, 206

${ }^{87}$ Tim Penyusun, KBBI, 105.

${ }^{88}$ E.M/ Blaikok, Surat-Surat Pengguru (Malang: Gandum Mas, 1972), 45.

${ }^{89}$ Arichea dan Hatton, Op.Cip, 97.

${ }^{90}$ Hendriksen, Op.Cip, 1.158.
} 
kemurnian hanya terdapat di dalam 1 Tim 4:12;5:2. dalam surat ini menunjukkan kepada sikap moral seseorang terhadap perempuan muda di dalam Kristus dan merupakan kemurnian yang mencegah suatu kenajisan dan roh atau sikap yang mengotori. ${ }^{91}$ Calvin mengatakan bahwa kemurnian bukan pertentangan dari ketidakbersihan, tetapi menunjukkan kemurnian seluruh hidup. ${ }^{92}$ Firitz Rienecker mengutip pendapat Kelly, bahwa bukan hanya menunjuk kepada kemurnian pada keadaan seksual tetapi juga menunjuk kepada keadaan tidak berdosa dan ketulusan hati yang merupakan suatu hubungan dalam kemurnian hati, pengetahuan, kesabaran dan dalam Roh Kudus dan kasih yang tidak munafik (2 Kor. $6: 6){ }^{93}$

Lock mengemukakan dalam buku Linguistic Key to the Greek New Testament dikatakan bahwa the word refers to purity of act and trought. ${ }^{94}$ Hal ini merujuk kepada pribadi yang mempunyai hati yang bersih atau kemurnian hati dan bergantung hanya kepada Tuhan, yakni dengan hati dan pikiran yang jernih.

Keenam, Keadilan. Kata "Keadilan" adalah kebajikan, kebenaran dan keadilan. Kittel menyatakan bahwa kata keadilan dipakai untuk orang-orang dalam Perjanjian Baru yang menunjuk pada tingkah laku yang Allah inginkan dan menyenangkan Allah. ${ }^{95}$ Artinya bahwa sikap seseorang pengajar memiliki hati dan pikiran yang sesuai dengan dasar hukum Allah, sehingga akan memimpin kepada tingkah laku dalam kekudusasn, dan hidup yang benar-benar saleh dihadapan Tuhan.

\footnotetext{
${ }^{91}$ Zodhiates, Op.Cip, 72.

${ }^{92}$ Jhon Calvin, Calvin's Commentaries Volume xxi. Galatians. Ephessians. Colossians. $1 \& 2$ Thess. $1 \& 2$ Timothty. Titus. Philemon. (Grand Rapids, Michigan:Baker Book House, 1993), 114.

${ }^{93}$ Clean Roger \& Firtz Rienecker, Linguistik Key to he Greek New Testament (Grand Rapids, Michigan:Zondervan Publishing House, 1980), 627-628.

${ }^{94}$ Roger and Rienecker, Op.Cip, 627-628.

${ }^{95}$ Gerhard Kittel, Op.Cip, 198.
}

Barclay mengemukakan bahwa keadilan berarti memberi baik kepada manusia maupun kepada Allah apa yang menjadi haknya. ${ }^{96}$ Di sini penulis melihat bahwa keadilan yang dimaksud memiliki dua aspek objek yaitu kepada manusia dan kepada Allah.

Ketujuh, Kesabaran. Kata "Kesabaran" adalah ketekunan, kesabaran, ketabahan dan ketekunan menantikan.. kata ini menekankan pada kemampuan untuk bertahan, tetap gigih dalam iman, tidak menyerah atau putus asa. Sikap ini perlu terutama apalagi waktu percobaan dan godaan datang. Kota Efesus bukanlah tempat yang paling mudah untuk mengurukan sebuah jemaat. Sungguh tidak mudah bagi Timotius mengurukan jemaat ini oleh karena berbagai masalah dan kesulitan yang terjadi dalam jemaat. Misalnya masalah tentang pengajar sesat yang sedang giat menjerat orang-orang Kristen (1 Tim. 1:3). Oleh karena itu, membutuhkan kemampuan untuk bertahan dalam menghadapi tantangan yang ada.

Barclay mengemukakan kesabaran berarti daya tahan atau kesabaran untuk mencapai kemenangan dengan keteguhan iman dan kesalehan yang tidak berubah yang walaupun dalam kesengasaraan dan penderitaan. ${ }^{97}$ Dengan demikian, kesabaran mengandung gagasan "bertahan", tetap bertahan walaupun menghadapi penderitaan. ${ }^{98}$ Hal ini dikarenakan kesabaran bukanlah berarti kepuasan diri sebab tidak melawan melainkan semangat yang terus mendorong melayani Tuhan tatkala menjalani penderitaan itu.

Kedelapan, Kelembutan. Kata "Kelembutan" adalah kesabaran. Wiersbe berpendapat bahwa "Kelembutan" bukan berarti kelemahan, tetapi berarti "Kekuatan yang terkendali". ${ }^{99}$ Itu berarti, sikap kelembutan bukan berarti pasrah diri tetapi sikap yang kuat tetap bertahan dalam kesulitan.

\footnotetext{
${ }^{96}$ Barclay, Op.Cip, 229-230.

${ }^{97}$ Barclay, Op.Cip, 229-230,

${ }^{98}$ Warren W. Wiesbe, Op.Cip,.98,

${ }^{99}$ Ibid, 99,
} 
Arichea dan Hatton mendefinisikan kata "Kelembutan" ini menjadi dua unsur. Pertama, artinya bisa "Kelembutan" atau "Sikap Rendah Hati". Kedua, berarti tidak kasar atau kejam dalam menghadapi orang lain atau memperlakukan orang lain dengan cara yang baik dan positif. ${ }^{100}$ Itu berarti, kelembutan adalah sikap diri yang mendalam dan keprihatinan kepada orang lain. Stott mengutip pendapat dari Lioyd-Jones mengatakan bahwa kelembutan adalah pendapat yang jujur dan ikhlas mengenai dirinya sendiri, dan benar-benar lembut sekaligus terpesona oleh kebaikan, tanggapan, perlakuan Allah dan manusia terhadap dirinya, yang sebenarnya tidak layak diterimanya. ${ }^{101}$ Dengan demikian, sikap kelembutan dalam menunaikan tugas merupakan sikap yang tulus, ikhlas mengerjakan tugas yang disertai dengan sikap yang tetap bertahan dalam kesulitan.

\section{Aspek Psikomotorik}

Guru PAK yang bertanggung jawab dalam melaksanakan tugas panggilannya adalah guru yang selalu mengembangkan dirinya. Oleh karena itu, tindakan seorang guru PAK penting dalam melaksanakan tugasnya.

Pertama, Melatih Ketekunan (1 Tim 4:16). Kata "Ketekunan" adalah bertahan lama, tetap melakukan. Tugas Timotius adalah mengajar ajaran sehat untuk umat di jemaat Efesus. Ajaran yang disampaikan dimaksudkan bukan hanya kegiatan mengajar saja, akan tetapi isi ajaran tersebut. Bertekunlah dalam semuanya itu secara harfiahnya adalah "tetaplah di dalamnya" yang dimasksud dengan "nya" adalah semua tugas dana kewajiban yang dibebankan kepada Timotius, yaitu sebagai pengajar, guru dan pemimpin jemaat. ${ }^{102}$

Kedua, Membaca Kitab Suci. Kata "membaca" adalah suatu kegiatan yang selalu

\footnotetext{
${ }^{100}$ Arichea dan Hatton, Op.Cip, 97,

${ }^{101}$ John R. W. Stott, Khotbah di Bukit, (Jakarta : Yayasan Komunikasi Bina Kasih/OMF,1988),50, 102 Arichea dan Hatton, Op.Cip, 101
}

dilakukan. Timotius pada dasarnya waktu kecil dia membaca Kitab Suci secara aktif. Dan masa pelayanannya pun dia dinasehatkan oleh Paulus supaya Kitab Suci itu terus dibaca.

Tradisi orang Yahudi membacakan kitab suci di tempat umum. Hendriksen mengemukakan bahwa pembacaan kitab suci di tempat umum biasanya di sinagoge (tempat ibadah) (Luk. 4:16; Kis. 13:15; 2 Kor. 3:14), tetapi dalam perjanjian Baru yang merupakan bagian untuk membangun jemaat (Kol. 4:16; 1 Tes. 5:27; Wah. 1:3). ${ }^{103}$ Oleh sebab itu, membaca Kitab Suci merupakan hal urgen dalam pelayanan Timotius. Karena di satu sis mengingatkan Timutius bahwa sejak kecil dia telah mengenal Kitab Suci (Bnd. 2 Tim. 3:15).

Wiersbe mengatakan, Membaca Firman Allah berarti membaca Kitab Suci di kebaktian umum dalam jemaat setempat. Orang-orang Yahudi selalu membacakan Kitab Taurat dan Kitab Para Nabi dalam rumah ibadat mereka, dan kebiasaan itu terbawa kepada jemaat-jemaat Kristen. Tuhan Yesus membacakan Kitab Suci dalam rumah ibadah Nazaret (Luk. 4:16, dst) dan Paulus sering membacakan pelajaranpelajaran dari Firman Allah apabila ia mengunjungi rumah ibadat (Kis. 13:15). ${ }^{104}$

Dengan jelas, membacakan Kitab Suci merupakan hal penting dalam pelayanan karena dengan membacakan firman salah satu peluang untuk menyampaikan dan menjelaskan isi Firman Tuhan. Bertekun dalam membacakan Kitab Suci erat hubungannya pernyembahan dan doa. Pelayanan Timotius di kota Efesus benarenar berada dalam kesulitan. Namun dalam kesulitan itu bukan berarti mengalah tetapi menyerahkan dirinya kepada Tuhan. Dalam pelayanannya Paulus menasehatkan dia supaya bertekun menunaikan doa syafaat kepada semua jemaat tanpa terkecuali (1 Tim. 2:1-7).

Ketiga, Membangun. Kata "Membangun" adalah menasehati, suatu hasutan

\footnotetext{
${ }^{103}$ Hendriksen, Op.Cip, 158.

${ }^{104}$ Warren W. Wiesbe, Setia di dalam Kristus, (Bandung Kalam Hidup, 1996), 68-69.
} 
atau dorongan. Timotius perlu menghibur, menguatkan hati dan menjawab dengan sukacita tatkala diperhadapkan dengan berbagai persoalan yang timbul dengan tujuan untuk menumbuhkan iman jemaat di Efesus Rienecker menyatakan, bahwa perbuatan dari nasehat, dorongan, motivasi, semua adalah fakta dari Kitab Suci yang merupakan suatu paraklesis, suatu nasehat, peringatan, teguran, nasehat yang baik atau dorongan untuk memperkuat, dan yang tidak bisa dipungkiri. ${ }^{105}$

Pengajar bukan hanya membaca firman kepada umat-Nya tetapi juga menasehati, mendorong mereka kepada ketaattan kepada Allah. ${ }^{106}$ Di sini penulis melihat bahwa Kitab Suci bukan hanya sekedar dibacakan saja tetapi setiap umat yang mendengar menjadi pelaku firman Tuhan itu (Yk. 1:22). Lebih lanjut Wiersbe mengatakan bahwa membangun berarti mendorong dan mengandung arti menerapkan firman Tuhan dalam kehidupan orangorang percaya. ${ }^{107}$

Keempat, Peliharalah Apa yang Dipercayakan. Kata "Peliharalah" adalah melakukan pengajaran, menjaga, mematuhi, berjaga. ${ }^{108}$ Berarti ka peliharalah dapat diartikan menjaga atau menghindarkan dari segala sesuatu yang merusak dalam pelayanan. Menurut Arichea dan Howard bentuk kata Yunainya menunjukkan bahwa Timotius perlu terus-menerus melakukannya. ${ }^{109}$ Berarti, Timotius perlu melakukan perlu melakukan apa yang telah dipercayakan kepadanya.

Paulus memberikan nasihat kepada Timotius: guard what has been es trusted to your care ${ }^{110}$ (Menjaga apa yang telah dipercayakan untuk kamu pelihara). Artinya bahwa Allah telah memberikan tugas mulia

\footnotetext{
${ }^{105}$ Rienecker. Op.Cip, 625.

${ }^{106}$ Earle. Op.Cip, 374.

${ }^{107}$ Warren W. Wiesbe, Setia di dalam Kristus, (Bandung Kalam Hidup, 1996), 69.

${ }^{108}$ Sutanto, Perjanjian Baru Interlinear Yunani-

Indonesia dan Konkordansi Perjanjian baru (PBIK) Jilid II. 801

${ }^{109}$ Arichea dan Hatton, Op.Cip, 168.

${ }^{110}$ Earle. Op.Cip, 389.
}

kepada Timotius untuk dipelihara. Kata "Peliharalah" secara harfiah berarti titipan. Ini adalah istilah resmi dunia peradilan barang atau hal yang dipercayakan kepada. ${ }^{111}$ Kata "Titipan" dipakai sebagai kiasan, namun tidak berarti hanya menyimpan saja tetapi tanggung jawab untuk melakukan segala sesuatu yang perlu dikerjakan. ${ }^{12}$

Dalam Pemahaman Alkitab sehari-hari Brown mengutip perkataan St. Vincentius menjelaskan kata Peliharalah berarti titipan, Itu adalah suatu yang diberikan kepadamu, bukan sesuatu yang engkau temukan, sesuatu yang telah engkau terima, bukan sesuatu yang telah engkau berikan, bukan sesuatu yang berasal dari kecerdasan, melainkan sesuatu yang berasal dari hasil belajar; bukan berasal dari asumsi pribadi, melainkan dari tradisi masyarakat; sesuatu yang dibawa kepadamu, bukan diambil dari mu; di mana kaummu bukalah penciptanya, melainkan penjaganya; bukan pimpinan, melainkan pengikut. Jaganlah titipan itu, lindungilah iman mu agar aman dan tidak berkurang; biarkan apa yang telah diberikan kepadamu telah bersamamu, untuk diserahkan kembali. Kamu telah menerima emas, kembalikan juga dalam bentuk emas. ${ }^{113}$

Penjelasan di atas menyatakan bahwa Timotius mendapat tugas pelayanan bukan atas dasar ambisinya semata, melainkan hanya kasih karunia Allah yang telah memilih dan memanggil dia sebagai pemberita Injil. Timotius mendapat tugas dengan sah melalui penumpangan tangan para penentu sebagai wakil Allah. Penumpangan tangan ini merupakan tradisi rasuli yang menyatakan bahwa tugas pelayaan diteruskan oleh Timotius. Oleh karena itu, Timotius perlu menjaga titipan itu dalam iman kepada Kristus. Allah telah menganugerahkan tugas ini dengan penyerahan dan pengabdian hidup kepada Tuhan. Dengan demikian, adapun wujud semua ini yaitu Injil dan pemberitaannya

\footnotetext{
${ }^{111}$ B. F. Drewes, dkk.Kunci Bahasa Yunani Perjajian Baru Surat Roma Sampai Kitab Wahyu, (Jakarta : BPK Gunung Mulia, 2006), 225.

${ }^{112}$ Arichea Op.Cip, 43.

${ }^{113}$ Barclay., Op.Cip, 217.
} 
serta pembinaan jemaat dalam menghayati imannya kepada Yesus, baik di dalam ajaran maupun dalam sikap yang manandai teladan, baik untuk perseorangan maupun untuk kehidupan jemaat. Semuanya mendatangkan kemuliaan nama Tuhan.

\section{Kajian Teologi Pedagogis}

\section{Guru PAK Memiliki Kerohanian yang Baik}

Guru PAK dalam mengemban tugasnya semestinya memiliki kerohanian yang baik. Karena guru PAK terpanggil untuk bertumbuh ke arah pengenalan tentang pribadi Yesus Kristus. Pengenalan Yesus akan memungkinkan guru PAK memahami kehendak Allah. Karena Yesus adalah jalan kebenaran dan hidup, yang membawa orang kepada pengenalan sejati tentang pribadi Yesus dan karya Allah. (Yoh. 1:18; 14:6).

Pengenalan Paulus tentang Allah membawa sebuah perubahan dalam dirinya. Paulus meninggalkan kedudukannya, kemegahannya, kekayaannya demi pengenal-an akan Kristus dan mengikut Dia (Flp. 3:7-8). Pengenalan Paulus tentang Allah diwujudnyatakan dengan sebuah persekutuan dengan sesama terlebih persekutuan dengan Bapa dan Anak-Nya Yesus Kristus (1 Yoh. 1:3). Persekutuan dengan Tuhan akan memiliki pertumbuhan dau kedewasaan teman. Oleh karena itu, pengenalan guru PAK tentang Yesus juga dimanifestasikan dengan persekutuan kepada Tuhan.

Pengenalan tentang Kristus akan membawa perubahan hidup. Demikian juga persekutuan dengan Tuhan membawa hidup lebih dekat kepada Tuhan. Dengan ini, guru PAK memiliki kerohanian yang baik dengan Tuhan. Oleh karena itu, persekutuan dengan Tuhan penting bagi seorang guru PAK. Dalam Ibrani 10:25a dikatakan: Janganlah kita menjauhkan diri dari pertemuanpertemunan ibadah. Teks ini dengan jelas menyatakan bahwa persekutuan dengan Tuhan merupakan keperluan bagi setiap guru PAK. Dengan demikian, guru PAK perlu memiliki persekutuaan dengan Tuhan supaya secara progresif bertumbuh dalam kedewasaan iman dan bergantung kepada Tuhan.

Guru PAK yang telah memiliki kedewasaan iman di dalam tubuh Kristus, akan menghasilkan buah iman. Artinya bahwa guru PAK hidup dalam kekudusan (1 Pet 1:15), hidup dalam kasih (1 Yoh. 4:7), serta bertumbuh di dalam Kristus (Ef. 4:15). Oleh karena itu, hal yang mewarnai hidup guru PAK dalam mengemban tugas panggilan yaitu memiliki pertumbuhan dalam kedewasaan iman. Stubblefiel mengatakan bahwa pertumbuhan iman dalam Kristus bukanlah persoalan pilihan bagi guru PAK. Tetapi sebuah teladan dari apa yang dimaksud dengan pertumbuhan dalam kedewasaan iman orang Kristen yang merupakan bagian dari pelayanan melalui kehidupan dan pekerjaan Gereja. ${ }^{114}$ Yesus memberikan teladan yang terdapat dalam Lukas 2:52 dikatakan: "Yesus makin besar dan bertambah hikmat-Nya dan besar-Nya, dan makin dikasihi oleh Allah dan manusia". Kata "makin" dalam bahasa Yunani secara harafiah artinya maju dengan pesat berarti ada pertumbuhan ukuran tubuh, kesadaran dan pemahaman-Nya. ${ }^{115}$ Ini berarti, Yesus bukan saja bertumbuh secara fisik tetapi makin bertumbuh ke arah pengenalan tentang Diri-Nya di hadapan Allah Bapa. Di mana Dia mempunyai kesadaran dan pemahaman tentang hubungan-Nya dengan Bapa-Nya. Yesus dalam pelayanan-Nya mengajar sesuai perintah Bapa-Nya. Dalam melaksanakan tugas-Nya, Dia tetap tunduk dan taat kepada Bapa-Nya. Oleh karena itu, sebagai seorang guru PAK mengikuti teladan dalam pelayanan-Nya. Guru PAK mesti memiliki pertumbuhan rohani dengan Tuhan. Di mana dia tidak hanya mengajar firman Tuhan tanpa merasakan dan menikman hadirat Tuhan dalam pelayanannya. Guru PAK mesti mengalami kebangunan rohani yang terus menerus bertumbuh di dalam Tuhan.

\footnotetext{
${ }^{114}$ Jerry M. Stubblefiel, The Effective Minister Of Education. (Nashville, Tennessee: Boadman \& Holman Publishers, 1993), 38.

${ }^{115}$ Pfeiffer dan Harrison, Op.Cip, 225.
} 
Melaksanakan tugas panggilan pelayanan dengan mengandalkan Tuhan. Sikap yang tunduk dan taat kepada Allah memberi kekuatan, kemampuan, sikap bijaksana dalam melaksanakan tugas panggilan pelayanan.

Dengan demikian, seorang guru PAK yang memiliki hubungan yang baik dengan Tuhan akan melaksanakan tanggung jawabnya dengan persekutuan dan penyerahan diri kepada Tuhan. Baik melalui doa, ibadah dan kekudusan diri yang terus menerus dilakukan di hadapan Tuhan.

\section{Guru PAK Melakukan Tugas dengan Cakap}

Seorang guru PAK terpanggil untuk mengerjakan berbagai tugas dan peranan penting dalam menunaikan tugasnya. Peranan sebagai pengajar firman Tuhan dan juga pemimpin Gereja. Kedua hal ini merupakan tugas yang seyogianya dikerjakan oleh guru PAK. Mengemban tugas ini tidak mudah, karena menuntut pertanggungan jawaban di hadapan Tuhan (Yak. 3:1). Oleh karena itu, guru PAK dalam menunaikan tugas dan tanggung jawab perlu benar-benar memiliki pribadi yang baik dan mantap atau cakap. Pribadi yang baik maksudnya tidak memiliki kondisi kesehatan yang buruk atau memiliki cacat tubuh, karena akan berakibat kurang baik terhadap proses pendidikan peserta didik serta mengakibatkan kesan yang baik di mata peserta didik dan juga masyarakat. Mantap mengacu kepada keahlian atau kemampuan dalam menunaikan tugas dengan bersandar atas hikmat pimpinan Tuhan.

Guru PAK merupakan seorang sosok yang menjadi pedoman bagi peserta didik. Hendricks mengatakan bahwa guru adalah objek pribadi yang kelihatan kepada orang lain dan yang membawa sebuah perubahan. ${ }^{116}$ Inilah yang sesungguhnya atribut seorang guru PAK, di mana segala tindakannya menjadi perhatian peserta didik dan juga masyarakat. Guru PAK sebagai inovatif kepada peserta didik. Oleh karena itu, guru

\footnotetext{
${ }^{116}$ Howard G. Hendricks, The Christian Educator's Hand Book On Teaching. (Canada, England: Victor Bodes, 1988), 243.
}

PAK perlu memiliki pribadi yang cakap melaksanakan tugas. Lebih lanjut Hendricks menegaskan bahwa jika guru tidak mengetahui ke mana dia pergi, bagaimana dia dapat memimpin orang lain. Jika ada orang tidak mengikut dia, dia bukan seorang pemimpin, he must be a person on influence. ${ }^{117}$ Ini berarti guru PAK dituntut memiliki kecakapan dalam melaksanakan tugas. Supaya orang lain dapat mengikuti pengajaran yang disampaikan. Oleh karena itu, guru PAK hendaknya menjadi seorang yang berpengaruh kepada orang lain.

Seorang pemimpin juga sebagai seorang pemimpin dan sebagai pemimpin perlu mengetahui pekerjaan yang dikerjakan. Dalam hal ini memerlukan kecakapan dalam mengerjakan tugas. Kecakapan yang dimaksud adalah memiliki kemampuan dan mengerti tugas yang dikerjakan. Eima mengatakan bahwa kecakapan seorang pemimpin dapat membangun atau mematahkan semangat juang memotivasi orang di sekelilingnya. Seorang pemimpin perlu mengetahui bagaimana cara melaksana-kan pekerjaannya. ${ }^{118}$ Ini berarti, kecakapan seorang guru PAK yang berperan sebagai pemimpin perlu memiliki kecakapan dalam melaksanakan tugas. Karena kecakapan bersifat membangun di mana bukan saja mengerti dan mampu melaksanakan tugas, tetapi menjadi menjadi berkat bagi orang lain. Karena itu melakukan tugas bukan asalasalan tetapi memiliki kesungguhan. Sehingga hasil karya yang dikerjakan menjadi berkat bagi orang lain. Oleh karena itu melakukan tugas dengan cakap artinya mengerti pekerjaan yang dilakukan.

Salomo mengatakan dalam Amsal 14:8 dikatakan: Mengerti jalannya sendiri adalah hikmat orang cerdik, tetapi orang bebal ditipu oleh kebodohannya. Ini berarti, dalam melaksanakan tugas diperlukan pengertian praktis yang menerapkan pengetahuan dan pengalaman yang ada pada pekerjaan itu. Artinya bahwa sebelum melasanakan tugas

\footnotetext{
${ }^{117}$ Hendricks, Op.Cip, 65.

${ }^{118}$ Leroy Eims, 12 Ciri Kepemimpinan Yang Efektif. (Bandung: Kalam Hidup, 2003), 157.
} 
terlebih dahulu mengerti tugas yang akan dikerjakan. Seorang guru PAK yang bijaksana mengerti tugas yang dilakukan dan tujuan yang perlu dicapai. Oleh karena itu hikmat dari Tuhan penting dalam melaksanakan tugas. Guru PAK yang cakap dalam melaksanakan tugas terus berpegang pada hikmat Allah. Mengerti pekerjaan yang dikerjakan, akan mengetahui yang Allah inginkan untuk di lakukan, dan terus berpegang pada hikmat Allah. Pekerjaan tidak dilakukan tanpa persiapan, tetapi terlebih dahulu memohon hikmat dari Tuhan. Dengan demikian, guru PAK yang melakukan tugas dengan cakap adalah guru PAK perlu mempunyai keterampilan dan kemampuan mengajar. Mengerti tugas yang dikerjakan. Mengerjakan tugas dengan hikmat Allah, membuat tugas yang dikerjakan berhasil (Mzm. 1:3).

\section{Guru PAK Menjadi Teladan}

Guru PAK merupakan panutan bagi para peserta didik maupun orang-orang percaya. Oleh karena guru PAK tugasnya sebagai pendidik dan pengajar. Guru PAK merupakan soko guru bagi peserta didik. Dikatakan sokoguru oleh karena guru yang menjadi peranan penting untuk menyampaikan pengajaran kepada peserta didik. Namun sebagai guru PAK tidak hanya menyampaikan pengajaran tetapi kepribadian yang menjadi teladan. Price mengatakan bahwa syarat yang terpenting bagi seorang guru ialah kepribadiannya sendiri. Sebuah teladan lebih berharga daripada nasihat Perbuatan seseorang lebih berpengaruh dari perkataannya. ${ }^{119}$ Ini berarti, keteladanan guru PAK penting dalam melaksanakan tugas panggilan pelayanannya. Keteladanan guru PAK bukan saja di saat melakukan proses belajar mengajar. Akan tetapi mencakup seluruh tindakan yang dilakukan. Memberi teladan yang berhubungan dengan sesama. Seperti perkataan, tingkah laku, kasih, kesetiaan,

${ }^{119}$ J. M Price, Yesus Guru Agung. (Bandung: Lembaga Literatur Baptis, 1997), 5. kesucian (1 Tim. 4:12), keadilan, kesabaran, kelembutan (1 Tim. 6:11). Teladan yang berhubungan dengan Tuhan seperti dalam hal beriman kepada Yesus, beribadah, Sikap seperti ini yang mencerminkan iman Kristen untuk dipratekkan guru PAK kepada orang lain.

Tuhan Yesus adalah guru Agung yang patut diteladani. la bukan saja dapat mengajar dengan berbagai metode tetapi memiliki sifat, perbuatan dan perkataan yang patut diteladani. Oleh karena itu, sebagai guru PAK yang menjadi teladannya adalah guru Agung yaitu Yesus Kristus. Guru PAK sebagai pengajar benar-benar menjadi teladan sama seperti Yesus menjadi teladan kepada murid-murid-Nya dan para pengikutnya.

Non Serranno mengatakan, Seluruh ajaran Yesus-dapat dilihat dengan jelas dalam pratek kehidupan-Nya sehari-hari. Ketika la mengajar mengenai berdoa, la selalu setia berdoa. Ketika la mengajar kerendahan hati, la membasuh kaki murid-murid-Nya. Ketika la mengajar mengenai pengampunan, la tidak mengutuk mereka yang melakukan kejahatan kepada-Nya. Ketika la mengajar tentang kasih, la mengasihi orang tanpa terkecuali...Yesus memiliki integritas tinggi, kata dan perbuatan-Nya selalu sejalan. ${ }^{120}$

Dengan jelas, bahwa Yesus mengajar bukan hanya teori saja yang hanya mengisi kognitif para pengikut-Nnya, Tetapi sebuah penerapan melalui sikap yang melakukan pengajaran yang disampaikan. Oleh karena itu, seorang guru PAK dituntut menjadi teladan bagi peserta didik. Guru PAK bukan hanya mengajar secara teoritis tetapi diikuti dengan pratek perbuatan yang sesuai dengan pengajarannya. Dengan demikian, guru PAK yang menjadi teladan adalah guru PAK hams mengaplikasikan pengajaran yang disampaikan kepada peserta didik.

\footnotetext{
${ }^{120}$ Janse Belandina Non-Serrono, Profesionalisme Guru dan Bingkai Materi :PAK SD. SMP. SMA, (Bandung: Bina Media Informasi (BMI), 2005), 18 .
} 


\section{Guru PAK Sebagai Pengkader}

Dalam Perjanjian Lama, para orangtua diperintahkan supaya dengan rajin dan tekun mengajar anak-anak tentang firman Allah dan memberi teladan hidup rohani (Ul. 6:7). Tujuannya supaya kasih dan hormat orangtua kepada Allah diteruskan dari generasi ke generasi supaya dapat mengasihi dan menghormati Allah. Yesus berkata kepada murid-muridNya, "Man, ikutlah Aku dan kamu akan Kujadikan penjala manusia" (Mat 4:19). Paulus mensihatkan orang-orang di Korintus "Jadilah pengikut, sama seperti aku juga menjadi pengikut Kristus" (1 Kor 1l:1). Paulus juga mengajarkan orang-orang di Filipi supaya mengikuti ajaran dan gaya hidupnya, dikatakan: "Apa yang telah kamu pelajari dan apa yang telah kamu lihat padaku, lakukanlah itu, maka Allah sumber damai sejahtera akan menyertai" (Flp. 4:19). Dan nasihat kepada Timotius untuk menerapkan pelayanan Gereja (1 Tim 4:1116). Berdasarkan perayataan ini, seorang seorang pelayan Tuhan memberi instruksiinstruksi kepada peserta didik untuk meneladani dan meneruskan pelayanan dalam mengajarkan pengajaran yang sehat. Sesungguhnya prinsip ini mewarnai tugas dan tanggung jawab guru PAK. Menyampaikan pengajaran, memberi teladan, serta memperlengkapi peserta didik untuk meneruskan tugas pelayanan Gereja.

Sebagai guru PAK tidak hanya berperan sebagai pengajar dan pendidik. Namun, guru PAK berperan sebagai pengkader. Artinya bahwa guru PAK melatih dan mengembangkan keterampilan, bakat serta penerapannya bagi peserta didik. Sebagai guru PAK perlu membimbing, mengawasi, mengarahkan peserta didik. Ini bermaksud supaya peserta didik dapat terdidik, terlatih dan terampil dalam pendidikannya. Dan menjadi generasi yang bertanggungjawab atas dirinya sendiri. Dalam buku Menjadi Guru Profesional dikatakan bahwa guru PAK bagaikan "Tongkat Musa" yang dapat dipakai oleh Allah untuk membina umat Tuhan agar lebih mengenal Dia (bnd. Kel. 4:4,20). ${ }^{121}$ Ini berarti, guru PAK memiliki sesuatu untuk disalurkan dan dialihkan kepada orang lain. Oleh karena itu, tugas dan tanggung jawab guru PAK mempersiapkan peserta didik untuk menerima peralihan tugas pengajaran yang sehat dan pelayanan Gereja.

Timotius adalah seorang anak rohani Paulus (1 Kor. 4:17; 1 Tim. 1:2; 2 Tim. 2:1). Timotius seorang yang meneruskan pelayanan orangtua rohaninya. Dalam buku Pemuridan Dengan Prinsip Timotius dikatakan bahwa bukan saja Timotius sebagai anak rohani, seorang anak yang sevisi dengan orangtua rohaninya, tetapi ia bisa mengambil alih pelayanan di bawah bimbingan orangtua rohaninya. ${ }^{122}$ Paulus telah mengajar, menasihati Timotius mengikuti teladannya dalam pelayanan. Dengan itu Paulus mengalihkan tugas pelayanan Gereja kepada Timotius. Seperti yang telah dilakukan oieh Musa kepada Yosua, Elia kepada Elisa dan Tuhan Yesus Kepada para rasul-Nya. Peralihan tugas pelayanan Gereja tidak terlepas dari bimbingan, nasihat dan pengajaran seorang guru PAK, karena dengan membimbing, menasihati dan mengajarkan ajaran yang sehat dapat membentuk karakter peserta didik sebagai seorang anak Allah yang hidup di dalam ketaatan kepada perintah Tuhan serta mengerti ajaran firman untuk dilakukan. Oleh karena itu, guru PAK perlu mengikuti teladan para rasul Allah dalam mempersiapkan para pengikutnya. Teladan peralihan tugas pelayanan Gereja penting, karena peserta didik sebagai generasi yang meneruskan mengerjakan dan bertanggungjawab dengan tugas panggilan pelayanan Gereja-Nya. Oieh sebab itu, guru PAK perlu mempersiapkan peserta didik dengan ajaran firman Tuhan, karena firman Tuhan merupakan pedoman dan dasar guru PAK membimbing, melatih,

\footnotetext{
${ }^{121}$ Sidjabat, Op.Cip, 49.

${ }^{122}$ Roy Robertson, Pemuridan Dengan Prinsip "Qmotjus, (Yogyakarta: ANDI OFFSET, 1999), 99.
} 
mengarahkan peserta didik sebagai kader penerima tongkat estafet pelayanan Gereja.

\section{Kesimpulan dan Saran}

Kesimpulan; Surat 1 Timotius ditulis sekitar tahun 62 atau $63 \mathrm{M}$ di Makedonia oleh rasul Paulus. Surat ini dialamatkan kepada Timotius dengan beberapa tujuan, yakni: Pertama, menasihatkan Timotius mengenai kehidupan pribadinya sebagai penerima tongkat estafet pelayanan Gereja. Kedua, mendorong Timotius untuk mempertahankan kemurnian Injil dari pengajaran sesat oleh guru-guru palsu. Ketiga, memberikan bimbingan kepada Timotius untuk menjadi pemimpin dalam mengurus Gereja di Efesus. Tugas utama yang mesti dikerjakan oleh Timotius adalah untuk memberitakan dan mengajarkan pengajaran yang sehat atau perkataan yang benar kepada orang-orang percaya yang ada di Efesus. Tujuannya untuk memurnikan Injil dari ajaran sesat dan jemaat Efesus dapat berbalik kepada Kristus dengan sungguh-sungguh dalam kebenaran Allah. Sebagai manusia, Timotius merasa tidak tidak layak mengemban tugas pengguruan anggota jemaat Allah di Efesus. Oleh karena Timotius merasa tidak mampu, tradisi orang Yahudi dan orang lain yang meremehkan dia. Oleh karena itu, Paulus menasihatkan dia sepertt seorang milker yang terus berjuang tanpa menyerah dengan perjuangan balk. Tujuannya untuk mendorong supaya tetap kuat dan berani memberitakan Injil.

Guru PAK sebagai petayan Tuhan berkewajiban untuk memberitakan Injil Kritus kepada umat-Nya. oleh karena itu, guru PAK mempergunakan segala potensi, talenta yang diberikan Tuhan untuk mengajar peserta didik. Bertanggungjawab dalam melaksanakan tugas. Mengajar dengan kebenaran Allah. Mengajar dengan otoritas Kristus. Mengajar dengan karunia Allah. Mengajarkan Injil dan menentang ajaran yang tidak sesuai dengan Injil Kristus. Hal ini bertujuan untuk membangun tubuh Kritus dalam kedewasaan iman jemaat Allan.
Seiring dengan itu, guru PAK perlu bangkit melawan tantangan zaman yang sedang terjadi.

Dengan demikian guru PAK dalam menunaikan tugas perlu memiliki kualifikasi sesuai firman Tuhan dalam surat 1 Timotius. Aspek rohani, bahwa hanya guru PAK mesti memiliki hubungan yang baik dengan Tuhan. Hubungan dengan Tuhan dilandasi dengan: Pertama, iman dan hati nurani. Iman memberi kekuatan untuk melakukan tugas. karena mencakup keyakinan kepada Tuhan. Hati nurani artinya perjuangan yang penuh dengan kerja keras, menyerahkan diri kepada Tuhan. Kedua, ibadah artinya sikap hidup yang saleh dihadapan Tuhan yang diwujudnyatakan dalam penyembahan kepada Tuhan. Aspek Kognitif yaitu pengetahuan yang dimiliki dalam melakukan tugas panggilan. pertama, cakap mengajar artinya terampil dalam mengerjakan tugas dan mengajar dengan mempergunakan hikmat Allah. Kedua, ajaran sehat artinya mengajarkan ajaran tentang Injil dari Allah yang mulia.

Aspek qfektif artinya sikap yang mencerminkan iman Kristen. Aspek ini merupakan teladan yang terdiri dari: Pertama, perkataan artinya guru PAK mesti mengucapkan perkataan yang benar kepada peserta didik juga kepada orang-orang percaya. Kedua, tingkah laku artinya cara hidup yang sesuai dengan norma dan nilainilai hidup. Ketiga, kasih artinya sebuah tindakan mengasihi orang lain dengan nyata tanpa mengharapkan balasan. Keempat, kesetiaan artinya sikap tetap percaya kepada Yesus, tetap setia, semakin dewasa di dalam iman. Kelima, kesucian artinya sikap memisahkan diri dari keinginan daging. Keenam, keadilan artinya sikap yang memperlakukan orang lain menerima apa yang menjadi haknya. Ketujuh, kesabaran artinya tetap bertahan tatkala menghadapi penderitaan. Kedelapan, kelembutan artinya sikap dalam kelembutan.

Aspek psikomotorik yaitu tindakan dalam mengemban tugas panggilan pelayanan. Pertama, mempunyai ketekunan artinya tetap berpegang pada ajaran sehat. Membaca Kitab Suci artinya belajar 


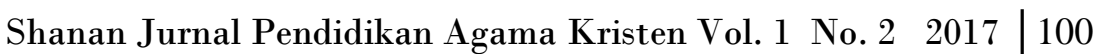

memahami firman Tuhan dalam menyampaikan serta menjelaskan isi firman Tuhan kepada umat. Membangun artinya menggurukan, menasihati jemaat dalam menerapkan firman Allah dalam kehidupan orang percaya. Kedua, peliharalah apa yang dipercayakan artinya menjalankan tugas dengan menghayati iman di dalam Kristus yang diwujudnyatakan atas kesungguhan melaksanakan tugas panggilan pelayanan.

Sebagai guru PAK memiliki kerohanian yang baik yang terus bersekutu dengan Tuhan. Melaksanakan tanggung jawab dengan cakap artinya mengandalkan hikmat Allah. Menjadi teladan mengajarkan peserta didik menghayati pengajaran untuk dilakukan. Sebagai pelatih untuk mempersiapkan peserta didik sebagai kader generasi penerus pelayan Gereja.

Saran; Penulis melihat bahwa guru PAK merupakan faktor penting dalam menyukseskan kegiatan belajar mengajar PAK. Oleh karena, kualitas peserta didik ditentukan oleh kualifikasi guru, maka peneliti memberikan beberapa saran.

Guru PAK diharapkan lebih sabar dan bertanggungjawab dalam mengajar apa pun kondisinya. Seperti nasihat Paulus kepada Timotius dalam surat 2 Timotius $4: 2 \mathrm{a}$ yang berbunyi "Beritakanlah firman, siap sedialah baik atau tidak baik waktunya".

Guru PAK yang memiliki tugas panggilan di lembaga pendidikan Kristen atau di sekolah negeri, swasta nasional hendaknya memiliki kredo bahwa bahwa dia seorang guru PAK atau pelayan Kristus. Tidak maju menunjukkan identitas sebagai pelayan Kristus supaya orang lain dapat bercermin dengan sikap dan tindakan setiap guru PAK.

Para guru PAK menyadari bahwa tugasnya tidak berakhir ketika selesai mengajar, tetapi hendaknya bertanggungjawab mempersiapkan kader baru generasi penerus pelayan Gereja.

\section{Daftar Pustaka}

Alkitab, JakartaL Lembaga Alkitab Indonesia, 2008.

Alkitab bahasa Yunani-Indonesia, Jakarta: Lembaga Alkitab Indonesia, 2007.

Good News Bible, New York: United Bible Socities, 1986.

Holy Bible King James Version (KJV), Grand Rapids, Michigan: Zondervan Publishing House, 1962. , Holy Bible New International Version (NIV), Grand Rapids, Michigan: Zondervan Publisher, 1977.

Aland, Kurt dan Aland, Barbara, The Greek new Testament, Jerman: United Bible Society New Testament, 1998.

Arichea, Daniel C. dan Hatton, Howard A., Pedoman Penafsiran Alkitab SuratSurat Paulus Kepada Timotius dan Kepada Titus. Jakarta Lembaga Alkitab Indonesia 2004.

Balz, Horst and Schneider, Gerhard (ed), Exegetical Dictionary of the New Testament Vol.2. Grand Rapids, Michigan: William B. Eerdmans Publishing Company, 1994. , Exegetical Dictionary of the New Testament Vot. 1, Grand Rapids, Michigan: William B. Eerdmans Publishing Company, 1994 , Exegetical Dictionary Of The New Testament,. Vol, 3. Grand Rapids, Michigan: William B. Eerdmans Publishing Company, 1994.

Bartlett, David L.. Pelavanan Dalam Perjanjian Baru. Jakarta: BPK Gunung Mulia, 2003.

Berkhof, Louis, Teologi Sistematika IV. Jakarta: Lembaga Reformed Injili Indonesia, 1997.

Blaiklok, E. M., Surat-Surat Pengguruan. Malang: Gandum Mas, 1972.

Boehlke, Robert R., Sejarah Perkembangan Pikiran dan Pratek Pendidikan Agama Kristen II. Jakarta: BPK Gunung Mulia, 2003. 
, Sejarah Perkembangan Pikiran dan Pratek Pendidikan Agama Kristen I. Jakarta: BPK Gunung Mulia, 2005.

Brugen Yakob Van, Siapa Yang Membuat Alkitab. Surabaya: Momentum, 2006.

Budiman, R., Tafsiran Alkitab Surat-Surat Pastoral 1. II Timotius dan Titus. Jakarta: BPK. Gunung Mulia, 1997.

Cains, I. J. Tafsiran Alkitab Kitab Ulangan 111. Jakarta: BPK Gunung Mulia, 1997.

Thess, $1 \& 2$ Timothy, Titus Philemon. Grand Rapids, Michigan: Baker Book House, 19931.

Calvin, John, New Testament Commentaries The Second Epistle Of Paul To The Corinthians, and The Epistles To Timothy. Titus and Philemon. Grand Rapids, Michigan: Wm. B. Eerdmans Publishing Company, 1980.

Chapman, Adina, Pengantar Perjanjian Baru, Malang: Gandum Mas, 2004.

Dick Mak, Pengantar Perjanjian Baru SuratSurat Paulus. Jakarta: Lip, 2008.

Douglas, J. D., Ensiklopedi Ajkjtab Masa Kini M-Z, Jakarta: Yayasan Kristen Bina Kasih (YKB)/OFM, 1996.

Drane, John, Memahami Perjanjian Baru. Jakarta: BPK Gunung Mulia, 2008.

Drewes, B. F., dkk., Kunci Bahasa Yunani Perjanjian Baru Surat Roma Sampai Kitab Wahyu. Jakarta: BPK Gunung Mulia, 2006.

Dufour, Xavier Leon-Ensiklopedi Perjanjian Baru Yogyakarta: Kanisius, 2008.

Earle, Ralph, The Expositor's Bible Commentary. General editor Frank E. Gaebelein. Grand Rapids, Michigan: Zondervan Publishing House, 1984.

Eims, Leroy, 12 Ciri Kepemimpinan Yang Efektif. Bandung: Kalam Hidup, 2003.

Erickson, Millard J., Teologi Kristen 3. Malang: Gandum Mas, 2003.

Free, Joseph P., Arkeologi dan Sejarah Alkitab. Malang: Gandum Mas, 2001.

Gasque, W. Ward, The Pickering Bible For to Dav, General Editor G. C. D. Howlev. London-Glasgow: Pickering dan Inglish, 1980.

Glare, P. G. W., Oxford Latin Dictionary. New York: Oxford At the Clareddon
Press, 1982 Grand Rapids, Michigan:

Baker Books, 2004.

Green, Jay P. The Interlinear Bible Hebrew Greek English. London, England: Hendrickson Publishers, 1986.

Groenen OFM, C., Pengantar Ke Dalam Perjanjian Baru. Yogyakarta: Kanisius, 2006.

Gultom, Andar, Profesionalisme. Standar Kompetensi. dan Pekembangan Profesi Guru PAK. (Bandung: Bina Media Informasi, 2007).

Guthrie, Donald, New Bible Commentary. Consulting Editors D. A. Carson, Leicester, England: InterVarsity Press, 1994.

Haak, C. J., I Timotius Pedoman Kehidupan Gerejani. ttp:tp., tth.

Hendricks, Howard G., The Christian Educator's Hand Book On Teaching. Canada, England: Victor Books, 1988.

Hendriksen, William, New Testament Commentary Thessalonians, The Pastoral, and Hebrew, Grand Rapis, Michigan: Baker Books, 2004.

Hendropuspito, D., Sosiologi Agama. Jakarta: BPK Gunung Multa, 2006.

Henry, Matthew, Matthew Henry's Corqmentarv In One Volume, Singapore:S+U Publishers, 1982.

Hoehner, Horald W., Ephesians An Exegetical Commentary. Grand Rapids, Michigan: Baker Academic, 2004.

Humes, Leatha dan Simanjuntak, A. Liake Penuntun Guru PAK SM dan SD1 dan II. Jakarta: BPK Gunung Mulia, 1999.

Isjoni, Dilema Guru, Yogyakarta: Sinar Baru Algesindo, 2007.

Kittel, Gerhard, Theological Dictionary of the New Testament (TDNT) vol. II. Grand Rapids: Wm. B. Eerdmans Publishing Company, 1980.

Knight,George W., The New International Greek Testament.Commentary (NIGTC) The Pastoral Epistles, Grand Rapids Michigan: William B. Eerdmans Publishing Company, 1992. 
Lase, Jason (Editor), Pendidikan Agama Kristen. Bandung: Bina Media Informasi (BMI), 2005.

Latuihamalo, P. D., dkk., Berakar di Dalam Dia dan di Bangun di Atas Dia. Jakarta: BPK Gunung Mulia, 2005.

Marshall, I. H. dkk., New Bible Dictionary, England: Inter-Varsity Press, Leicester, 1996.

Marxsen, Willi, Pengantar Perianjian Baru. Jakarta: BPK Gunung Mulia, 2008.

Morris, Leon, Teologi Perjanjian Bam. Malang: Gandum Mas, 1996.

Mulyasa, E., Menjadi Guru Profesional. Bandung: Remaja Rosdakarya, 2005.

Nainggolan, John M., Menjadi Guru Agama Kristen. Jabar: Generasi Info Media, 2007.

Nggebu, Sostenes, Dari Batsaida Sampai Ke Yerusalem, Malang: Kalam Hidup, 2002.

Non-Serrono, Janse Belandina, Profesionalisme Guru dan Bingkai Mated PAK SD. SMP. SMA. Bandung: Bina Media Informasi (BMI), 2005.

Packer, J. I., dkk., Ensiklopedi Fakte Alkitab. Malang: Gandum Mas, 2004.

Pfeiffer, Charles F. and Harisson, Everett F., The Wyclife Bible Commentary Old Testament Cichago: Moody Press, 1981.

Perschbacher, Wesley J., The New Analytical Greek Lexicon. Peabody, Massachusetts: Hendrickson Publishing, 1990.

Pfeiffer, Charles F. dan Harrison, Everett F., The Wycliffe Bible Commentary. Chicago: Moody Bible Institute, 1962.

Polhill, John B. Paul and His Letter. Nashville, Tennessee: Broadman and Halman Publishers, 1999.

Price, J. M., Yesus Guru Agung (Bandung: Lembaga Literatur Baptis, 1997.

Purwanto, Ngalim, Psikologi Pendidikan, Jakarta: Remaja Rosdakarya, 2006.

Richards, Lawrence O., New International Encyclopedia, of Bible Words, Grand Rapids: Zondervan Publishing House, 1991.
Robertson, Roy, Pemuridan Dengan Prinsip Timotius. Yogyakarta; ANDI OFFSET, 1999.

Robinson, John A. T, Redating The New Testament Eugene: Wipf and Stock Publishers, 2000.

Roger, Clean \& Rienecker, Frtz, Linguistik Key to the Greek New Testament Grand Rapids, Michigan: Zondervan Publishing House, 1980.

Sidjabat B. S., Menjadi Guru Profesional. Bandung: Kalam Hidup, 2000.

Stibbs, A. M., Tafsiran Alkitab Masa Kini 3. Jakarta: Yayasan Kristen Bina Kasih (YKBK), 2007.

Stott, John R. W., II Timotius. Jakarta: YKBK, 2007.

Stubblefiel, Jerry M., The Effective Minister Of Education, Nashville, Tennessee: Boadman \& Holman Publishers, 1993.

Sumanto, Metode Penelitian Yogyakarta: Andi Offset 1999.

Sumiyatiningsih, Dien, Mengajar Dengan Krcatif \& Menarik, Yogyakarta: ANDI OFFSET, 2007.

Sutanto, Hasan, Perjanjian Baru Interlinear Yunani- Indonesia dan Konkordansi Perjanjian Baru (PBIK) Jilid II. Jakarta: Lembaga Alkitab Indonesia, 2004.

Tenney, Merrill C., Survei Perjanjian Baru, Malang: Gandum Mas, 2006.

Tim Penyusun, Kamus Besar Bahasa Indonesia $(K B B I)$. Jakarta: Balai Pustaka, 2007.

Tulluan, Ola Introduksi Perjanjian Baru. Jakarta: Yayasan Persekutuan Pekabaran Injil Indonesia YPPII, 1999.

William, Barclay, Surat 1 dan 2 Timotius, Titus, Filemon. Jakarta: BPK _ Gunung Mulia, 2001. 